Article

\title{
Regional Heterogeneity of Migrant Rent Affordability Stress in Urban China: A Comparison between Skilled and Unskilled Migrants at Prefecture Level and Above
}

\author{
Tingzhu Li ${ }^{1}$, Ran Liu ${ }^{1, *}$ and Wei $\mathrm{Qi}^{2}$ \\ 1 College of Resource Environment and Tourism, Capital Normal University, No.105 West 3rd Ring Road \\ North, Beijing 100048, China; litingzhuz@foxmail.com \\ 2 Institute of Geographical Sciences and Natural Resources, Chinese Academy of Sciences, Beijing 100101, \\ China; qiwei@igsnrr.ac.cn \\ * Correspondence: liu.ran.space@hotmail.com
}

Received: 27 September 2019; Accepted: 21 October 2019; Published: 24 October 2019

check for updates

\begin{abstract}
Rental housing unaffordability has been widely used to assess the housing poverty problem among immigrants in the developed and developing countries. China is experiencing an unprecedented urbanization process, with two-thirds of its 250 million migrants now being sheltered in private rental housing in the host cities. In this paper, we aimed to examine the rental housing unaffordability problems faced by migrant workers in urban China and provide policy recommendations for a more accessible and affordable migrant housing provision system. We used the household data on China's Migrant Dynamics Monitoring Survey (MDMS), released in 2016, across China's 329 prefecture-level cities and above to look into the sociality and spatiality of migrant rent expenses and rent-income ratio at the prefecture-level cities and above. The statistical tests were conducted to examine the socio- and spatial-variance of these rent stress indexes, and it was found that educational level is a significant and quite powerful indicator in predicting who will or will not assume the heavier rental housing pressure. We then continued to reveal the different spatiality of high-rent-stress migrants across the high- and low-skilled categories. An agglomeration of the high-skilled high-rent-stress migrants was witnessed in the coastal growth engines of urban clusters, while a more spillover-like pattern among the low-skilled high-rent-stress migrants was reported in our study. An ordinary least square and spatial regression analysis was conducted to explain their respective mechanisms.
\end{abstract}

Keywords: internal migration; mainland China; regional heterogeneity; rent affordable stress; skilled migrants; unskilled migrants; prefectural cities

\section{Introduction}

Richard Florida's creative class theory has exerted an increasingly significant impact in today's regional sciences and urban geography studies [1]. Compared with the overwhelming role of capital in attracting talent, talent itself is also a more and more effective and attractive factor to attract capital [2]. Florida pointed out that the great metropolises with high shares of skills, creativity, and knowledge would inevitably have high wages and housing costs borne by high-skill and low-skill occupations across the American metropolises [3]. Empirically and theoretically, the most creative people prefer living in places that provide better housing security, greater freedom, and more cultural opportunities [4]. With the deepening marketization of housing system and the increasing housing demands in the developed and developing countries, the crisis of the real estate bubble has generally 
occurred [5]. China has experienced the largest massive rural to urban migration in human history, of around 250 million internal migrants on the move in 2015 [6,7]. Housing is an important aspect of the basic needs of urban migrants, but a person with a rural hukou status is still not fully eligible for state-sponsored housing assistance in urban areas [8,9]. Many studies have revealed that the most important decision for migrants is rental housing [10-14]. The housing problem is quite challenging among the unskilled migrants, who are limited to certain lower-level sections of the urban job market and thus have lower capacities to afford the urban housing market [15]. Furthermore, the flow of talent has effectively affected the development of the knowledge economy, and the amenity-driven mobility of talent has become the new geographical phenomenon in recent years in China [16,17].

The announcement of the National New Urbanization Plan (2014-2020) by the Chinese government in 2014 has marked a huge change of Chinese urbanization policy towards a more inclusive growth pattern [18]. The regional differences of urbanization patterns in the more and less advanced areas in China will persist, and such areal heterogeneity is expected to bring with them many problems with housing, employment, medical care, social security and education provisions for the migrant workers $[19,20]$. The great variance between cohorts has attracted much attention, too, as the old rural workers (nongmingong, known as migrant labors from rural areas) and the new-generation migrant workers (those born in the 1980s and afterwards) coexist together in the huge labor market in the Chinese metropolises. The Chinese internal migration pattern has changed remarkably due to the inflow of a new generation of migrants as the main force of internal migration [21]. The new-generation migrants who are motivated by the superior urban lifestyle and prosperous career development in the big cities are generally better educated and skilled, and are more likely to work in the advanced manufacturing industries and the well-paid service industries than in the traditional construction industry, based on Richard Florida's study and an empirical observation on China's industrial upgrading [1-3]. At the same time, as Chinese higher education is undergoing the process of universalization, the young generation has gotten better trained and they are more capable of engaging in skilled jobs [22]. For this reason, the skilled migrant population has grown and is better equipped for the great economic restructuring in Chinese cities. It is apparent that the skills of highly-educated migrants have contributed to their superior positions in the labor and housing markets compared with their unskilled peers, which results in a different residential distribution in cities [23]. The housing affordability capacities, the consumption preference and behaviors in the housing market of skilled migrants are therefore distinct from the unskilled ones. But the divide of migrant rent affordability stress between skilled and unskilled migrant workers and the regional heterogeneity of this stress in urban China have rarely been reported in the existing literature.

At the same time, another profound institutional reform on the hukou system is proceeding, but cities of different administrative ranks in China have taken different actions as to how to better attract, serve, and manage the migrant workers in the destination cities [24]. The releasing of hukou constraints and the "talent war" between second tired cities are believed to be the reactions of local governments towards population aging and an impending drop in China's demographic dividend in recent years in urban China [25-29]. It is reported that the decline of demographic dividend has prompted some cities to introduce a young and high-skilled labor force to improve the demographic structure in the aging regions, rust belts, and those experiencing industrial upgrading [30,31]. Interestingly, despite the very strict $h u k o u$ regulation and housing purchase limits on migrants in first-tier cities such as Beijing and Shanghai, second-tier cities including provincial capital cities like Wuhan and Zhengzhou have provided very generous housing subsidies in order to attract the young high-skilled migrants who have a bachelor's degree and above [32,33]. The regional variance in terms of housing policy towards migrant workers has been a new policy incentive explaining the new trends of internal migration in China now [34].

The housing difficulties of migrant workers have been repeatedly reported $[7,10,14,15]$, but the gap of rental housing pressure between high- and low-skilled migrants has got very little attention in China. Under the background of the new hukou and talent policy in China, this paper will look into 
the demographic and socio-economic divide between high- and low-rent-stress migrant workers in China based on the 2016 data of China's Migrant Dynamics Monitoring Survey (MDMS), which was conducted by the National Health and Family Planning Commission in China. The educational level of migrants is identified as the most prominent indicator of their rent stress situation, nationwide. We thus analyzed the regional heterogeneity and mechanism of high- and low-skilled migrant rental housing stress, respectively. The research results provide solid proof about the role of educational levels in stratifying and predicting the rent stress problem among migrant workers in China, and also highlight the importance of diversifying the rental housing policy for different migrant groups (highvs. low-skilled migrants) in the different kinds of cities in China.

\section{Literature Review}

\subsection{Housing Problems Faced by High- and Low-Skilled Migrants}

For nearly half a century, with the rapid rural-to-urban migration and the deepening of housing marketization, rental and housing prices have risen sharply in Chinese cities and a housing bubble crisis has emerged as a result [34]. It is believed that immigration into a certain region would lead to a sizeable increase in housing demands and thus bring about an increase in housing costs among the migrant households [35]. Gonzalez, according to his empirical study on the relationship between immigration and housing bubbles, pointed out that a migration-driven one percent increase in population would lead to an increase in house prices of 1 to 1.6 percent in the following year, and a 0.8 to 1 percent increase in the number of dwellings, in the context of Spain [36]. It was also reported in American cities that an immigration flow that increased the population by one percent would lead to a one percent increase in housing rents and three percent increase in house prices [37]. In terms of the housing market of the USA, Ottaviano suggested that the rent elasticity of immigration was around 0.7 , and between 1 and 2 for housing prices, using the data from the U.S. states [38]. The negative correlations between emigration and housing costs were observable as well. Bohn found that in the USA, the increase in emigrants had reduced the rental housing demands based on the effects of Arizona's Legal Arizona Workers Act (LAWA) law on the housing rental market [39]. Arbaci concluded that the unfavorable social conditions and housing patterns of immigrants in contemporary Southern Europe (involving limited public housing production and few opportunities for self-built housing) have triggered socio-residential exclusion, peripheralization and de-segregation in the context of urban renewal and gentrification [40].

Recent studies have revealed the importance of geographical elements (such as the distance, accessibility, neighborhood effects, spatial autocorrelation, spatial heterogeneity, multi-scalar effects, and multi-level effects) in explaining housing supply structure and its close relation towards the urban agglomeration process [41]. The research has covered the perspectives of housing supply structure and housing demand issues. Based on this, Glaeser presented a model of housing bubbles which predicted that places with more elastic housing supply would have fewer and shorter bubbles and, also, smaller price increases [42]. In terms of housing demand, Saiz found that the promotion of the housing demand of migrants would lead to an increase in rental housing prices, but a decline in the income of migrants would reduce housing demands and, thus, rental levels [43]. Antoniucci revealed that the larger immigrant populations coincided with the steeper housing price gradients on a national scale in 112 Italian provincial capitals [44]. In contrast, in another empirical research on Castel Volturno, Italy, Forte confirmed that the unique socio-economic conditions of this case study had induced the local real estate market to be avulsed from its macroeconomic dynamics, leading to a reduction of housing prices among the immigrant population [45].

In recent years, the production and spillover of knowledge have exerted an increasingly stronger influence on the economic development in cities [46-48]. The role of talent in the shaping of new economic geographical landscapes has attracted much attention [1,2,12,13]. From this perspective, Florida suggested that, given the spillover effects in the accumulation of human capital, these talents 
would be more productive when they locate around each other with high levels of human capital, especially in the great metropolises $[49,50]$. This explains the reason why human capital is usually strongly associated with urban agglomeration and regional growth. With an accelerated revolution of modern technology, the labor demand in the both developed and developing countries is in profound change as well. For example, Berman suggested that labor-saving technological change was one of the chief explanations for the shift in labor demand away from the unskilled and toward skilled labor in U.S. manufacturing, over the 1980s till now [51]. Tammaru pointed out that residential context was not an important factor in explaining workplace segregation for immigrant men, and that the most important factors shaping workplace segregation pertained to economic sector and city size for newly arrived immigrant men and women from the less developed areas to Sweden [52].

In a word, over the past decades, the employment structure has been changing from traditional manufacturing jobs to more diversified job demands, including professionals and managers [53]. The skilled migrants have grown sharply in the Chinese cities, too, with the economic restructuring and an accelerated labor mobility. Against the background of diverse employment opportunities, the number of highly-educated and high-skilled migrant workers has increased significantly [23]. Because of the less developed economy and the less diversified labor market in small cities, a high proportion of high-skilled migrants prefer moving to the larger cities, and they show a strong tendency to settle down permanently in big cities [54]. In the coming knowledge economy era, Florida argued that a more efficacious approach to regional development would be to emphasize policies and programs to attract human capital, as opposed to the conventional approaches that focus on the attraction of firms and the formation of industrial clusters [50]. Lee pointed out that the cities that can provide housing opportunities would be more likely to attract high-skilled migrants, and the amenity-driven mobility of talent can contribute greatly to the urban development of the knowledge economy [55]. Meanwhile, Berry's study on the "creative class" in Melbourne had drawn attention to the role of the housing market in underpinning the inflow of talent and the development of a knowledge-based economy as a result [56]. Because professional and managerial staff are becoming increasingly wealthier and nowadays place more stress on urban amenities, leisure pursuits and work-life balance, these skilled migrants have placed more importance on amenity-related issues including an affordable and decent housing supply in the destination cities [57]. Moreover, with the rapid development of transportation and communication technology, high-skilled migrant mobility is becoming more and more flexible for being not as sensitive to the commuting time or home-job mismatch as before. On the contrary, they prefer the cities which can provide a comfortable dwelling environment and other amenities [58].

The globalization, industrialization, and urbanization process in the past four decades in China has promoted large numbers of skilled migrants to move to the cities [54,57]. The migration of skilled labor is becoming a significant aspect of internal migration in China; and for them, owning a home (not merely obtaining a local hukou) in the destination city is viewed as a milestone for their long stay and permanent settlement [59]. But in fact, socio-spatial differentiation and housing inequality exist between local-nonlocal groups and also between migrants at different hierarchical positions in the urban labour market, especially in the large Chinese cities such as Beijing, Shanghai, Guangzhou, and Shenzhen [60-62]. Despite housing problems, high-skilled migrants are still more likely to move permanently to the Chinese metropolises, including those in high administrative hierarchies and with new economy agglomerations (such as IT, media, R\&D) [63]. Migrants who are highly skilled and well educated, on the other hand, are welcomed by urban governments to obtain local urban hukou (including talent cards) and become permanent migrants [32-34]. Many migrants have access to governmental housing such as talent apartments, low-rental public housing, and other types of subsidized housing in the destination cities in China [53-55].

For the above reasons, high- and low-skilled migrants are faced with different challenges in accessing affordable and decent housing in the host cities $[64,65]$. Compared with high-skilled migrants, most of the low-skilled migrants are engaged in the lower-end industries, and their income level and housing affordability capacity are therefore below the average of permanent residents [66-68]. 
Hainmueller found that low-skilled migrants are usually in a passive position in their work and daily life in the destination cities [69]. Housing costs have been rapidly rising with the population explosion and the consequent rapid urban land expansion, while the affordable housing supply has been not augmented; as a result, housing poverty and unaffordability are becoming acute problems for low-skilled and low-wage migrants in urban China [70]. Although the Chinese government has paid attention to the housing problem of migrants since the announcement of the "National New Urbanization Plan" (2014-2020) and has introduced a series of guarantee policies (such as low-rental housing supply), little effect has been achieved to benefit low-income migrants in the past several years [34,62]. In addition, macro-regulation by the central government was unsuccessful in preventing housing rental and prices rising, as revealed in Ye's previous studies [71]. At the local level in many cities, the municipal government-sponsored public housing schemes and monetary housing subsidies are still not open to migrants, especially low-skilled migrants who do not hold a local hukou in China [70]. A majority of migrants have relied on private rental housing, provided more likely by real estate corporations and agencies and also by individual households in urban China [72], and also by the urban villages as well as urban peripheral areas in the rural-urban interface of the metropolitan areas in Beijing, Guangzhou, and Shenzhen [73,74].

\subsection{Rent Unaffordability Measurement}

The increasing housing stress faced by migrant workers has become a global challenge, and it is well known that the housing unaffordability crisis significantly affects the long stay of migrant populations in the destination cities [75-78]. Scholar research on the housing affordability of migrant workers has focused mainly on the sources of housing problems, dynamic changes in the housing market, housing supply policies in the various environments, and the measurement of housing affordability. Over nearly 40 years, the definitions and measurement methods of housing affordability have evolved from being unidimensional towards being a comprehensive computation across multi-dimensions. As early as the 1970s, the American government had made policies on its urban rental housing market to cure the rental unaffordability crisis. Initially, the threshold of rent-income ratio as to what was deemed rental unaffordability was set at 25 percent [79-81]. Nelson pointed out that rental housing affordability was a relative relationship between income and expense rather than an inherent housing feature [82]. According to Nelson, if the ratio of rental expense to income is reasonable, the family can be considered to be able to afford housing; otherwise, it indicates that the households are under a heavy stress of rental costs [82]. In the past half century, the reasonable range of rent-income ratio has been calculated and augmented from 25 to 30 percent in the United States [83]. Generally speaking, rent affordability stress is heavier in the metropolitan areas than that in the less developed areas [60-62]. According to the 1996 Canadian census data, nearly 20 percent of households in the Montreal metropolitan area had a rent-to-income ratio of more than 50 percent [84].

The measurement of housing affordability has proceeded with the improvements of recognition on the sources of housing unaffordability. At first, the measure of urban poverty considered only the adequacy of family food, but Sen pointed out that family poverty was not only caused by the shortage of food, but also by housing consumption [85]. Housing poverty has thus attracted a lot of attention. For low- and medium-income families, high housing expenses may reduce housing affordability and family benefits, which means that families would not have the enough funds to meet other needs besides housing expenses [83-85]. Based on this new concept, Stone constructed another model to measure the maximum value of housing expense, that is, the non-housing expense deducted from the total family income [83]. Meanwhile, Kutty introduced the concept of housing poverty to measure housing affordability stress, whether families can afford other expenses after paying for housing expenses [86]. Besides, Hulchanski studied the dynamics of rent stress, and pointed that rental housing expense and family income were specific factors that affected rental housing affordability [87]. Wang found that the ratio of tenants, migrants, wage, land cost, and the housing market had a significant impact on rental housing affordability in China [88]. Cai evaluated housing affordability by selecting 
the more integrative indictors such as the housing poverty rate, housing costs and transportation costs, and found that the comprehensive framework was more explanatory when living costs was included in the model [89].

In addition, the spatiality of rental housing affordability is another research topic in recent years. Many studies have revealed that the rental housing affordability stress is not only unevenly distributed among social groups, but also presents a significantly unbalanced distribution in space $[86,90]$. For example, Bunting examined rental housing affordability in Canada based on a geographical perspective and revealed that rental housing stress decreased from urban centers to the suburbs [84]. Moreover, some literature has suggested that location, such as the accessibility of transportation, is also a key factor affecting rental housing affordability stress [91]. Owing to the fast urbanization path in China, the top-tier cities (Beijing, Shanghai, Guangzhou, and Shenzhen) have displayed a great spatial difference of migrant rental housing stress from lower-tier cities, as well as the inner-metropolitan areas in China [92]. Li examined the spatial patterns and determinants of housing rents in Shanghai, and found that high rents were concentrated heavily in the inner-city area, which forced low-income families to move to the suburbs [93]. Concerning the spatial pattern of housing rental, Hu suggested that the high-high clusters of housing rental prices merged in the central districts, whereas the low-low clusters of housing rental prices were located in the outskirts, based on the housing rent prediction models in Shenzhen [94]. Although quite a lot of literature has analyzed the spatial difference of migrant rent stress in China's metropolitan areas, little attention has been paid to the inter-city variance of it at the prefecture city scales. This research will focus on the spatial distribution of migrant rent stress at the prefecture city scale in China today, and the spatial difference of rent stress between high- and low-skilled migrants across prefecture-level cities in China.

\section{Materials and Methods}

\subsection{Conceptual Framework}

This paper designs a research framework to explore the socio-economic and spatial inequalities of migrant rental housing pressure (Figure 1). This research links the sociality with spatiality of rental housing pressure among Chinese migrant workers in order to better reveal the migrants' rent affordability stress problems in transitional China. The Chinese cities at prefecture level and above are selected as the research scale in this paper, as the existing research was rarely conducted on prefecture city scales. As shown in Figure 1, the analysis procedures of this paper will follow three steps. Firstly, based on the data of China's Migrant Dynamics Monitoring Survey (MDMS) in 2016, we use the regression analysis method (ordinary least square, known as OLS) to examine the determinants of migrant rent stress, and it was concluded that education was the most significant factor besides income level to predict whether the migrants had high rental housing pressure or not. Second, owing to the great variance in rental housing pressure between high- and low-skilled migrants, we continue to compare the spatial distribution patterns of high-rent-pressure migrants with high- and low-skills, respectively. The distinctly different spatial patterns of rental housing pressure between the high- and low-skilled migrants are reported and mapped in this section. Finally, we used the spatial regression model (spatial error model and spatial lag model) to analyze the mechanism of the spatial patterns of high-rent-pressure migrants with the high- and low-skills, respectively. 


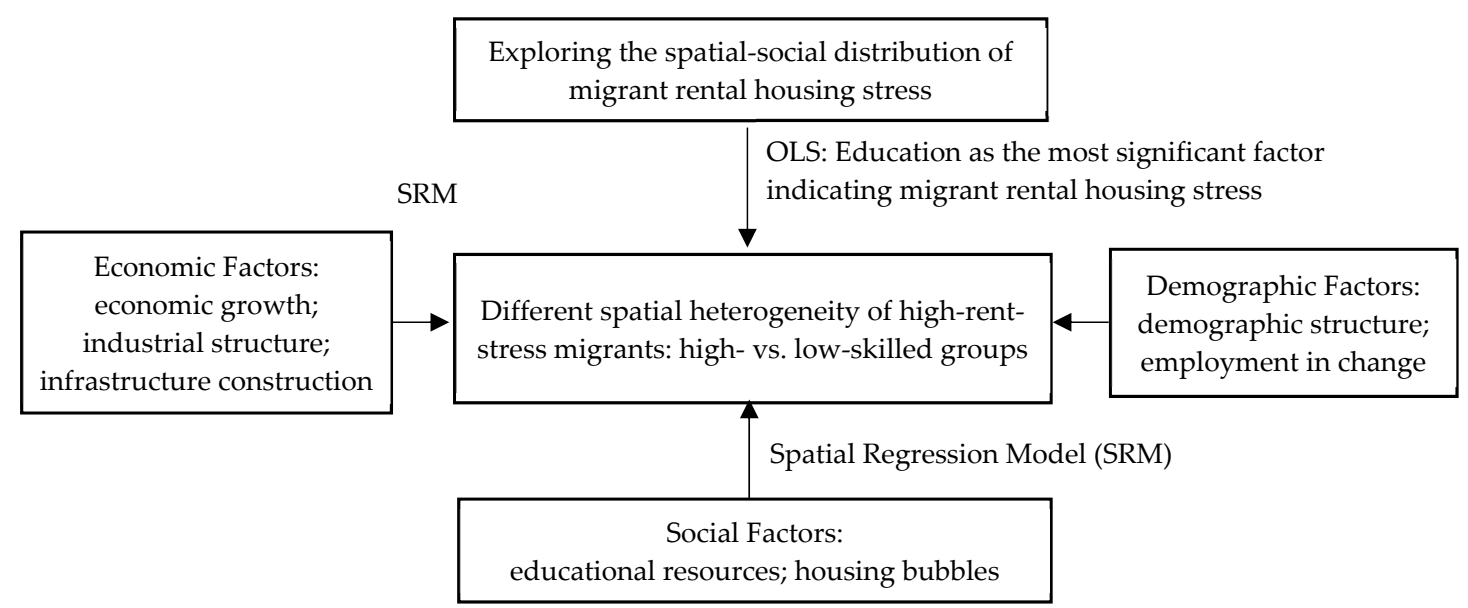

Figure 1. The conceptual framework of spatial heterogeneity of migrant rental housing pressure in China (Note: Ordinary least square is known as OLS, and spatial regression model is known as SRM).

\subsection{Data}

The data used in this paper is from China's Migrant Dynamics Monitoring Survey (MDMS) in 2016. Our research questions focus on the spatial distribution and its dynamics of high- and low-skilled migrant rental housing stress in 329 prefecture-level and above cities in China in 2016. This paper selects samples whose residential community type is termed "neighborhood committee" in the urban areas and whose housing type is "private rental house" from the MDMS in 2016. This sample database has included 67,674 households according to the above criteria, and does not involve those living in the urban villages that are informal housing with incomparable rental value from one city to another in China.

\subsection{Methods}

\subsubsection{Global Moran's I Coefficient}

The spatial autocorrelation (Global Moran's I) tool measures spatial autocorrelation based on both feature locations and feature values simultaneously. According to Tobler's First Law in Geography that "while everything is related to everything else and near things are more related than distant things" [95], the spatial autocorrelation (dependence) in this article refers to the potential dependence between observed objects and those in the same region.

Given a set of features and an associated attribute, it evaluates whether the pattern expressed is clustered, dispersed, or random. The tool calculates the Moran's I index value and both a $z$-score and $p$-value to evaluate the significance of the index.

The Moran's I statistic for spatial autocorrelation is given as

$$
\mathrm{I}=\frac{\mathrm{n}}{\mathrm{S}_{0}} \frac{\sum_{\mathrm{i}=1}^{\mathrm{n}} \sum_{\mathrm{j}=1}^{\mathrm{n}} \mathrm{w}_{\mathrm{i}, j} \mathrm{z}_{\mathrm{i}} \mathrm{z}_{\mathrm{j}}}{\sum_{\mathrm{i}=1}^{\mathrm{n}} \mathrm{z}_{\mathrm{i}}^{2}}
$$

where $i$ and $j$ are different cities in this research, $z_{i}$ is the deviation of an attribute for city $i$ from its mean $\left(x_{i}-x\right), z_{j}$ is the deviation of an attribute for city $j$ from its mean $\left(x_{j}-x\right), w_{i, j}$ is the spatial weight between city $i$ and $j, n$ is equal to the total number of cities, and $S_{0}$ is the aggregate of all the spatial weights.

$$
\mathrm{S}_{0}=\sum_{\mathrm{i}=1}^{\mathrm{n}} \sum_{\mathrm{j}=1}^{\mathrm{n}} \mathrm{w}_{\mathrm{i}, \mathrm{j}}
$$

When the $z$-score or $p$-value indicates statistical significance, a positive Moran's I index value indicates tendency toward clustering while a negative Moran's I index value indicates tendency 
toward dispersion. Particularly, spatial weights are a key component in the cross-sectional analysis of the spatial dependence, involving the contiguity- or distance-based spatial weights and some more complicated measurements on it. According to Yu, D.L. and Wei, Y.H.D. [96], their empirical research on Chinese cities has constructed spatial weights matrices based on distance strategies. Their $80 \mathrm{~km}$ choice in their paper was based on their field experience. It was the distance of approximately an hour's drive on the expressways in their research region of the Chinese cities. We borrowed the $80 \mathrm{~km}$ choice from Yu, D.L. and Wei, Y.H.D.'s studies; that is, the geographic units within $80 \mathrm{~km}$ are deemed spatially linked neighbors in this research [96].

\subsubsection{Getis-Ord Gi *}

The Getis-Ord local statistic is assumed to be

$$
G_{i}^{*}=\frac{\sum_{j=1}^{n} w_{i, j} x_{j}-\bar{X} \sum_{j=1}^{n} w_{i, j}}{S \sqrt{\frac{\left[n \sum_{j=1}^{n} w_{i, j}^{2}-\left(\sum_{j=1}^{n} w_{i, j}\right)^{2}\right]}{n-1}}}
$$

where $x_{j}$ is the attribute value for city $j, w_{i, j}$ is the spatial weight between city $i$ and $j, n$ is equal to the total number of cities and

$$
\begin{gathered}
\bar{X}=\frac{\sum_{j=1}^{n} x_{j}}{n} \\
S=\sqrt{\frac{\sum_{j=1}^{n} x_{j}}{n}-(\bar{X})^{2}}
\end{gathered}
$$

where $\bar{X}$ is the mean of the corresponding attribute, $S$ is the standard deviation, the $G_{i}^{*}$ statistic is a $z$-score so no further calculations are required. For statistically significant positive $z$-scores, the larger the $z$-score is, the more intense the clustering of high values (hot spot). For statistically significant negative $z$-scores, the smaller the $z$-score is, the more intense the clustering of low values (cold spot).

\subsubsection{Ordinary Least Square}

This paper empirically analyzes the driving factors of migrant rental housing stress from the aspects of household characteristics and employment factors based on the literature in recent years [97]. There are 12 variables in this regression model, and all the category variables are recoded as the dummy variables (Table 1) [98].

In this study, we choose rental housing expense and rent-to-income ratio as dependent variables, respectively. The models are expressed as follows:

$$
\begin{gathered}
\text { LogExpense }_{\mathrm{i}} \text { Ratio }_{\mathrm{i}}=\alpha_{0}+\alpha_{1} \text { Gender }_{\mathrm{i}}+\alpha_{2} \text { Education }_{\mathrm{i}}+\alpha_{3} \text { Marriage }_{\mathrm{i}}+\alpha_{4} \text { Hukou }_{\mathrm{i}}+\alpha_{5} \text { Length }_{\mathrm{i}}+ \\
\alpha_{6} \text { Origin }_{\mathrm{i}}+\alpha_{7} \text { Family }_{\mathrm{i}}+\alpha_{8} \text { Income }_{\mathrm{i}}+\alpha_{9} \text { Industry }_{\mathrm{i}}+\alpha_{10} \text { Employer }_{\mathrm{i}}+ \\
\alpha_{11} \text { Contract }_{\mathrm{i}}+\alpha_{12} \text { Insurance }_{\mathrm{i}}+\varepsilon
\end{gathered}
$$

where LogExpense and Ratio are dependent variables, $i$ is unit, $\alpha_{0}$ is constant, $\alpha_{1} \ldots \alpha_{12}$ are coefficients, and $\varepsilon$ is random error. The regression results will be analyzed on two different scales: (a) at the national scale involving all the samples; and (b) at the regional scales to look into the regional variance of the driving factors of migrant rental housing stress across the East China, Central China, West China, and Northeast China. 
Table 1. Independent variables and their definitions in ordinary least square (OLS).

\begin{tabular}{|c|c|}
\hline Variables & Definition \\
\hline \multicolumn{2}{|l|}{ Household Factors } \\
\hline Gender & Male $=0$, Female $=1$ \\
\hline Education & $\begin{array}{l}\text { Low }(\text { Senior high school and below })=0, \\
\text { High (College and above) }=1\end{array}$ \\
\hline Marriage & Unmarried $=0$, Married $=1$ \\
\hline Hukou & Rural $=0$, Urban $=1$ \\
\hline Length & Length of residence \\
\hline Origin of Region & $\begin{array}{l}\text { Ref }=\text { East China, } \\
\text { Central China, } \\
\text { West China, } \\
\text { Northeast China }\end{array}$ \\
\hline Family Size & The family living in destination city \\
\hline \multicolumn{2}{|c|}{ Employment Factors } \\
\hline Income & Household income per month, unit: Yuan (Log) \\
\hline Industry Type & $\begin{array}{c}\text { Ref = secondary industry, } \\
\text { Primary industry, } \\
\text { Producer service, } \\
\text { Public service, } \\
\text { Consumer service }\end{array}$ \\
\hline Employer Type & $\begin{array}{c}\text { Ref = Privately-owned enterprises, } \\
\text { State-owned enterprises, } \\
\text { Collective-owned enterprises, } \\
\text { Foreign direct investment enterprises, } \\
\text { Family- or individually-owned business, } \\
\text { Non-profit organization } \\
\text { Other = Unemployed, retired, etc. }\end{array}$ \\
\hline Contract Type & $\begin{array}{c}\text { Ref }=\text { long-term labor contract, } \\
\text { Short-term labor contract, } \\
\text { Temporary labor contract, } \\
\text { Other = Self-employed and other types }\end{array}$ \\
\hline Insurance Type & $\begin{array}{c}\text { Pension insurance, } \mathrm{No}=0, \text { Yes }=1 ; \\
\text { Unemployment insurance, No }=0, \text { Yes }=1 ; \\
\text { Injury insurance, No }=0, \text { Yes }=1 ; \\
\text { Maternity insurance, No =0, Yes = } 1 ; \\
\text { Medical insurance, No = } 0, \text { Yes }=1 ; \\
\text { Housing Provident Fund, No }=0, \text { Yes }=1\end{array}$ \\
\hline
\end{tabular}

\subsubsection{Spatial Regression Models}

In order to examine the sources of regional inequality in rental housing stress, it is necessary to understand the mechanism behind the differentiation of rental housing stress. The studies of regional inequality often adopt varieties of conventional regression methods, such as the ordinary least squares (OLS) that is most commonly used, generalized method of moments (GMM), and maximum likelihood (ML). But in the event of which spatial autocorrelation exists and is, thus, unable to be eliminated from the model, the spatial regression model (SRM) would then be conducted. Two types of SRM model can be produced which is the spatial lag model (SLM) and spatial error model (SEM). This research used both sets of the complementary regressions in order to investigate the directions of impact factors affecting high- and low-skilled migrants with high rent affordable stress at the city level in China. A 
spatial lag model (SLM) was used to reflect the impact of spatial units on other near units in the whole region. The SLM can be computed in equation by

$$
\mathrm{y}_{\mathrm{i}}=\sigma \sum_{\mathrm{j}=1}^{\mathrm{n}} \mathrm{W}_{\mathrm{i}} \mathrm{y}_{\mathrm{j}}+\beta \mathrm{x}_{\mathrm{ik}}+\mu_{\mathrm{k}}+\varepsilon_{\mathrm{i}}, \varepsilon_{\mathrm{i}} \sim \mathrm{k} \cdot \mathrm{k} \cdot \mathrm{d}\left(0, \delta^{2}\right)
$$

where $i=1, \ldots, 329$ denotes the spatial location of cities in China; $y_{i}$ is the dependent variable (the number of high-rent-stress migrants); $x_{i k}(\mathrm{k}=1, \ldots, 7)$ is the seven independent variables, including GDP, SAT, FAI, POT, PPS, EDU, and HP (abbreviations defined in Table 2); $\beta$ is the local regression parameters to be estimated; and $\sigma$ is the correlation coefficient in spatial regression, which reflects the spatial dependence of the objects. $W_{i}$ is a diagonal weighting matrix. The data of GDP, SAT, FAI, PPS, and EDU are derived from the China City Statistical Yearbook in 2016, POT from the Migrant Dynamics Monitoring Survey in 2016, and HP from the China Real Estate Statistics Yearbook [99-101].

Table 2. Independent variables and their definitions in the spatial regression model (SRM).

\begin{tabular}{ccc}
\hline & Variables & Definition \\
\hline \multirow{3}{*}{ Regional Economic Factors } & GDP & Gross Domestic Product in each city \\
& SAT & Secondary and tertiary industries as share in GDP \\
& FAI & The fixed asset investment in each city \\
\hline \multirow{2}{*}{ Regional Demographic Factors } & POT & Proportion of tenants in migrants \\
& PPS & Proportion of producer services in urban jobs \\
\hline \multirow{2}{*}{ Social Factors } & EDU & Per capita public spending on education \\
& HP & Housing price in each city \\
\hline
\end{tabular}

Spatial autocorrelation may exist among the variables. Given that the independent error term may impact on the spatial spillover effects that exist between geographic units, spatial autocorrelation with no independent error term may lead to biased or even misleading conclusions being drawn. A spatial error model (SEM) can solve this problem of the error term. The SEM is generally based on the following autoregressive model:

$$
\mathrm{y}_{\mathrm{i}}=\beta \mathrm{x}_{\mathrm{ik}}+\mu_{\mathrm{k}}+\varphi_{\mathrm{i}}, \varphi_{\mathrm{i}}=\rho \sum_{\mathrm{i}=1}^{\mathrm{n}} \mathrm{W}_{\mathrm{i}} \varphi_{\mathrm{i}}+\varepsilon_{\mathrm{i}},\left[\varepsilon_{\mathrm{i}} \sim \mathrm{k} \cdot \mathrm{k} \cdot \mathrm{d}\left(0, \delta^{2}\right)\right]
$$

where $\rho$ is the spatial autocorrelation coefficient of error term; $\varphi$ is the error term of spatial autocorrelation.

\section{Results}

\subsection{The Spatial-Social Distribution of Migrant Rental Housing Pressure}

\subsubsection{The Spatial Distribution of Migrant Rental Housing Pressure}

Over the past two decades, the housing rental market in China has grown rapidly and gained considerable attention, along with the flourishing of the housing sales market. According to the MDMS in 2011 and 2016, the mean of migrant rent expenses has soared from 533 yuan in 2011 to 1022 yuan in 2016 [100,102]. The mean of migrant rent-income ratios has risen from 14.5 percent in 2011 to 16.4 percent in 2016 [100,102]. Since the announcement of the National New Urbanization Strategy by the Chinese government in 2014, the Chinese urbanization policy has changed to a more inclusive growth pattern [14]. Although the number of migrants has declined a bit in 2015, there are still 245 million migrants on the move in China in 2016 [99,100]. These migrants' rental housing pressure has varied across the different regions and different cities. As shown in Figure 2a, migrant rent in the eastern and southwestern regions is generally higher than that in the central and northwestern regions. 
The cities with high rental expense in East China are mainly first-tier cities such as Beijing, Shanghai, Nanjing, Shenzhen, which are the growth engines of the whole region that are able to provide better jobs and higher incomes for migrant workers [18]. In the central region, migrants in Zhengzhou, Wuhan, and Changsha spend apparently more on rental housing than their peers in the surrounding cities. Meanwhile, migrants have a higher rent in cities which have the advantageous industries such as high-tech and tourism in the western region in China.
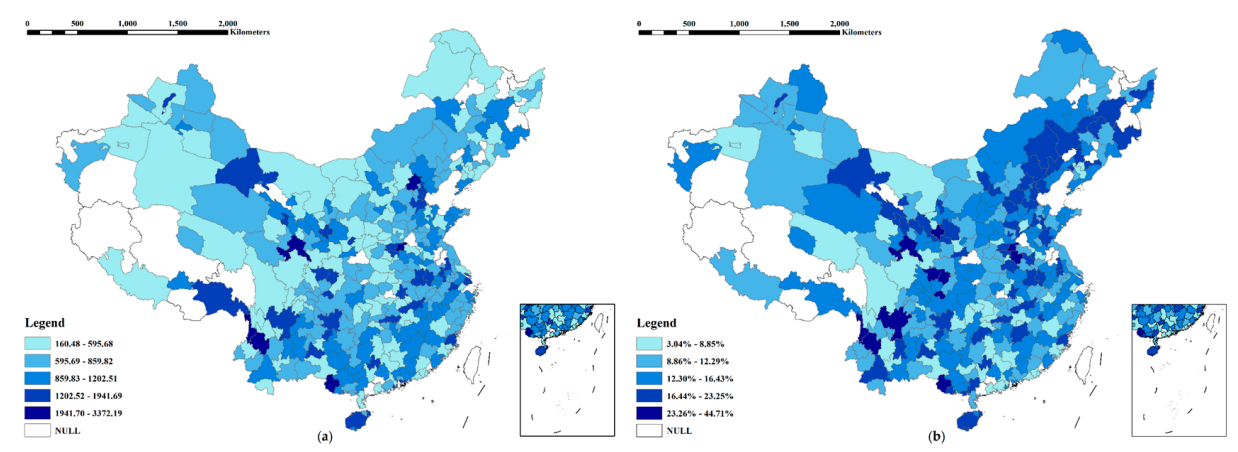

Figure 2. Migrant rental housing stress: (a) household rental expense; (b) household rent-income ratio.

The rent-income ratio is a commonly used indicator to measure rental housing affordability [103]. As shown in Figure 2b, we divide the migrant rent-income ratio into five levels by using Jenks in ArcGIS (known as Jenks Natural Breaks Classification or Optimization). The high ratio (above 16.44 percent) indicates that the heavy rental housing stress is mainly distributed in the northeast, northwest, and southwest regions in mainland China. The migrant rent-income ratio in the southeast region is generally lower than that in north China, and the high rent-income ratio is mainly scattered in the particular provincial capital cities such as Fuzhou. It can be seen that the rent-income ratio is distributed continuously in the northeast and northwest regions in China. This distribution pattern of migrant rent-income ratios is almost consistent with China's regional variance in terms of economic development patterns, where the growth path and regional gap across the southeast, northeast, and southwest regions in the mainland China is prominent and persisting over the years [104].

The spatial mismatch between migrant rent expenses and rent-income ratios may attract much attention as well. As shown in Figure 2, migrant rental housing stress is much higher in some economically backward cities such as Guang'an in Sichuan Province and Guyuan in Ningxia Province. But the rental levels in these cities are generally low. This indicates that the low wage level of migrants in these areas can hardly match the relatively high rent there [105]. In the process of industrial transformation, traditional industries with low added value still occupy a relatively high proportion of less advanced areas, such as Guang'an and Guyuan, with high rent stress [106]. Interestingly, southeast China, with rapid economic upgrading, has witnessed low rental housing stress among the migrant workers as migrant household incomes are relatively high and their rent-income ratios are generally low there, thus indicating a high rental housing affordability among migrants in the coastal southeast areas. For example, the urban agglomeration in the Pearl River Delta (PRD) is more habitable for migrant workers, as migrant rent is high but the rent-income ratio is low [107].

\subsubsection{The Social Attribution of Migrants with Rental Housing Stress}

In this study, the main determinants that can explain the differences in migrant rental housing affordability stress in urban China are analyzed. The regression model on migrant housing expenses and rent-income ratios is constructed, respectively, using household characteristics and employment factors that are composed of a total of 12 explanatory factors as independent variables. As reported in Table 3, the adjusted $R$ squared value is 0.406 and 0.258 in explaining the variance of migrant housing expenses and rent-income ratios on the national scale in urban China, respectively. The main findings are elaborated as follows. 
Table 3. Overall results of OLS model on migrant rental expenses and rent-income ratios.

\begin{tabular}{|c|c|c|c|c|c|c|c|c|c|c|}
\hline \multirow{2}{*}{ Variables } & \multicolumn{5}{|c|}{ Rental Expenses (Log, unit: yuan) } & \multirow[b]{2}{*}{ East } & \multicolumn{4}{|c|}{ Rent-Income Ratio } \\
\hline & East & Central & West & Northeast & Nation & & Central & West & Northeast & Nation \\
\hline Gender & -0.007 & -0.005 & 0.004 & $-0.050 * *$ & $-0.012^{* *}$ & -0.007 & -0.005 & 0.005 & $-0.049 * *$ & $-0.013^{* *}$ \\
\hline Education & $0.175^{* * *}$ & $0.132 * * *$ & $0.145^{* * *}$ & $0.124 * * *$ & $0.160 * * *$ & $0.201 * * *$ & $0.145^{* * *}$ & $0.151^{* * *}$ & $0.122 * * *$ & $0.179 * * *$ \\
\hline Marriage & $-0.042 * * *$ & $-0.048^{* *}$ & $-0.038^{* *}$ & 0.001 & $-0.041 * * *$ & $-0.048 * * *$ & $-0.053 * *$ & $-0.039 * *$ & 0.000 & $-0.046^{* * *}$ \\
\hline Hukou & $0.118^{* * *}$ & $0.038^{* *}$ & $0.113^{* * *}$ & $0.054^{* *}$ & $0.101 * * *$ & $0.136^{* * *}$ & $0.042 * *$ & $0.118^{* * *}$ & $0.053^{* *}$ & $0.113^{* * *}$ \\
\hline Length of residence & 0.020 ** & $-0.059 * * *$ & $-0.035^{* * *}$ & $-0.130 * * *$ & $-0.014^{* *}$ & $0.023 * *$ & $-0.065^{* * *}$ & $-0.036^{* * *}$ & $-0.128^{* * *}$ & $-0.016^{* *}$ \\
\hline \multicolumn{11}{|l|}{ East (ref) } \\
\hline Central & $-0.067^{* * *}$ & $0.026^{* *}$ & $0.033^{* * *}$ & 0.011 & $-0.067^{* * *}$ & $-0.077^{* * *}$ & $0.029^{* *}$ & $0.035^{* * *}$ & 0.011 & $-0.075^{* * *}$ \\
\hline West & $-0.100^{* * *}$ & $-0.069 * * *$ & 0.012 & $0.039 * *$ & $-0.107^{* * *}$ & $-0.114^{* * *}$ & $-0.076^{* * *}$ & 0.013 & $0.038^{* *}$ & $-0.119^{* * *}$ \\
\hline Northeast & $0.033 * * *$ & 0.022 & 0.010 & $-0.034 *$ & $0.016^{* *}$ & $0.038^{* * *}$ & 0.024 & 0.010 & $-0.033 *$ & $0.017 * *$ \\
\hline Family size & $0.054^{* * *}$ & $0.080^{* * *}$ & $0.029 * *$ & $-0.066 * *$ & $0.047^{* * *}$ & $0.061^{* * *}$ & $0.088^{* * *}$ & 0.030 ** & $-0.065 * *$ & $0.052 * * *$ \\
\hline Income ( $\log )$ & $0.385^{* * *}$ & $0.426^{* * *}$ & $0.362 * * *$ & $0.342 * * *$ & $0.407^{* * *}$ & $-0.297^{* * *}$ & $-0.219 * * *$ & $-0.316^{* * *}$ & $-0.329 * * *$ & $-0.304^{* * *}$ \\
\hline \multicolumn{11}{|l|}{ Industry type } \\
\hline \multicolumn{11}{|l|}{ Secondary (ref) } \\
\hline Primary & 0.011 * & 0.015 & $-0.035^{* * *}$ & $-0.053^{* *}$ & -0.006 & $0.012 *$ & 0.016 & $-0.036^{* * *}$ & $-0.053^{* *}$ & -0.007 \\
\hline Producer service & $0.198^{* * *}$ & $0.133 * * *$ & $0.145^{* * *}$ & $0.188^{* * *}$ & $0.188^{* * *}$ & $0.227^{* * *}$ & $0.146^{* * *}$ & $0.152 * * *$ & $0.185^{* * *}$ & $0.210^{* * *}$ \\
\hline Public service & $0.130 * * *$ & $0.119 * * *$ & $0.104^{* * *}$ & $0.089 * * *$ & $0.128^{* * *}$ & $0.150^{* * *}$ & $0.131^{* * *}$ & $0.109 * * *$ & $0.088^{* * *}$ & $0.144^{* * *}$ \\
\hline $\begin{array}{l}\text { Consumer service } \\
\text { Ownership }\end{array}$ & $0.251^{* * *}$ & $0.172 * * *$ & $0.203^{* * *}$ & $0.273^{* * *}$ & $0.248^{* * *}$ & $0.288^{* * *}$ & $0.189^{* * *}$ & $0.211^{* * *}$ & $0.268^{* * *}$ & $0.278^{* * *}$ \\
\hline \multicolumn{11}{|l|}{ Privately (ref) } \\
\hline State-owned & $-0.013^{*}$ & $-0.107^{* * *}$ & $-0.047^{* * *}$ & $0.041 * *$ & $-0.038^{* * *}$ & -0.015 * & $-0.118^{* * *}$ & $-0.049^{* * *}$ & $0.041 * *$ & $-0.042 * * *$ \\
\hline Collective-owned & 0.002 & 0.005 & $0.019 *$ & 0.019 & $0.009 * *$ & 0.002 & 0.006 & $0.019 *$ & 0.018 & $0.010 * *$ \\
\hline Foreign & $-0.023^{* *}$ & $-0.026^{*}$ & 0.003 & $0.045^{* *}$ & $-0.021^{* * *}$ & $-0.026^{* *}$ & $-0.028 *$ & 0.003 & $0.044^{* *}$ & $-0.024^{* * *}$ \\
\hline Family/individual & $0.024 * *$ & 0.011 & 0.005 & $0.046 * *$ & $0.019 * *$ & $0.028 * *$ & 0.012 & 0.006 & $0.045 * *$ & $0.022 * *$ \\
\hline Non-profit & -0.004 & $-0.033 * *$ & 0.009 & 0.026 & -0.001 & -0.005 & $-0.036 * *$ & 0.009 & 0.026 & -0.001 \\
\hline Other & -0.009 & -0.008 & $-0.042 * * *$ & -0.008 & $-0.015^{* *}$ & -0.010 & -0.008 & $-0.044^{* * *}$ & -0.008 & $-0.016^{* *}$ \\
\hline \multicolumn{11}{|l|}{ Contract } \\
\hline \multicolumn{11}{|l|}{ Long-term (ref) } \\
\hline Short-term & 0.002 & $-0.017 *$ & 0.001 & $-0.048^{* *}$ & -0.002 & 0.002 & -0.018 & 0.001 & $-0.048^{* *}$ & -0.002 \\
\hline Temporary & $-0.062 * * *$ & -0.032 & $-0.078^{* * *}$ & $-0.157^{* * *}$ & $-0.065^{* *}$ & $-0.071 * * *$ & $-0.035 *$ & $-0.082 * * *$ & $-0.155^{* * *}$ & $-0.073 * *$ \\
\hline Other & 0.002 & 0.016 & 0.010 & -0.037 ** & 0.003 & 0.003 & 0.017 & 0.010 & $-0.037^{* *}$ & 0.004 \\
\hline \multicolumn{11}{|l|}{ Insurance } \\
\hline Pension & $-0.015 *$ & $0.098^{* * *}$ & 0.006 & 0.050 & $0.011 * *$ & -0.017 * & $0.108^{* * *}$ & 0.006 & $0.049 * *$ & $0.013^{* *}$ \\
\hline
\end{tabular}


Table 3. Cont

\begin{tabular}{|c|c|c|c|c|c|c|c|c|c|c|}
\hline \multirow{2}{*}{ Variables } & \multicolumn{5}{|c|}{ Rental Expenses (Log, unit: yuan) } & \multirow[b]{2}{*}{ East } & \multicolumn{4}{|c|}{ Rent-Income Ratio } \\
\hline & East & Central & West & Northeast & Nation & & Central & West & Northeast & Nation \\
\hline Unemployment & $-0.094^{* * *}$ & -0.009 & $-0.158^{* * *}$ & $-0.043 *$ & $-0.092^{* * *}$ & $-0.108^{* * *}$ & -0.010 & $-0.164^{* * *}$ & -0.042 & $-0.102^{* * *}$ \\
\hline Injury & $0.028 *$ & $0.138^{* * *}$ & $0.128^{* * *}$ & 0.076 & $0.078 * * *$ & $0.033 *$ & $0.151^{* * *}$ & $0.134^{* * *}$ & $0.075 *$ & $0.087^{* * *}$ \\
\hline Maternity & 0.030 ** & $-0.191 * * *$ & -0.034 & -0.043 & $-0.028 * *$ & $0.035^{* *}$ & $-0.210 * * *$ & -0.036 & -0.042 & $-0.032 * *$ \\
\hline Medical & -0.015 & $-0.063 * *$ & 0.000 & -0.042 & -0.023 ** & -0.017 & $-0.070 * *$ & 0.000 & -0.041 & $-0.026^{* *}$ \\
\hline HPF & $-0.068^{* * *}$ & 0.018 & -0.012 & 0.015 & $-0.047^{* *}$ & $-0.078^{* * *}$ & 0.020 & -0.012 & 0.014 & $-0.052 * * *$ \\
\hline Constant & 0.526 & 0.251 & 0.692 & 0.984 & 0.562 & 0.526 & 0.251 & 0.692 & 0.984 & 0.562 \\
\hline$p$-value & 0.000 & 0.000 & 0.000 & 0.000 & 0.000 & 0.000 & 0.000 & 0.000 & 0.000 & 0.000 \\
\hline $\operatorname{Adj} R^{2}$ & 0.477 & 0.322 & 0.294 & 0.245 & 0.406 & 0.311 & 0.183 & 0.233 & 0.267 & 0.258 \\
\hline
\end{tabular}

Note: ${ }^{*} p<0.1,{ }^{* *} p<0.05,{ }^{* * *} p<0.01$. 
Firstly, among the migrant household characteristics, the gender gap is reportedly significant to explain a higher or lower level of their rental housing affordability stress. Males have significantly higher rent expenses and also a higher rent-income ratio than females. Married migrants reported lower rental housing stress, probably owing to the economic contribution of double wage earners in a marriage. An urban hukou status is another significant indicator here. The migrant households with an urban hukou tend to choose to pay higher housing costs in exchange for a more comfortable living environment in the host cities; but those with a rural origin may prefer urban villages that are more affordable in order to minimize unnecessary consumption in their transitory migration phase. Besides, a larger family size dwelling together in the destination cities can predict a stronger housing consumption demand and therefore a higher rent-income ratio. Interestingly, the migrants from eastern China have reported more severe rental housing stress than those from central and western China, probably because migrant workers from the less advanced central and western China would intentionally reduce rental housing costs to relieve other aspects of living stress in the destination cities [70].

The education level of migrants is very closely correlated to rental expenses and rent-income ratios, as reported in Table 3. Migrants with an educational attainment of high school or below are categorized as low-skilled. Those with a higher educational background such as college and above are deemed as high-skilled [49]. This high- and low-skilled duality is widely used in the previous internal migration studies in China today, as conducted by Cui and Liao $[23,59,108]$. The OLS regression analysis shows that the education level is not only a significant independent variable $(p=0.001)$ interpreting the migrants' high or low rental housing stress, but also one of the most prominent indicators in the regression results, following income and industry types (see Table 3). It is apparent that high-skilled migrants generally have a stronger housing affordability capacity and, at the same time, a better pursuit of decent housing, social prestige, and comfortable dwelling environments than their low-skilled peers [69]. Therefore, the high-skilled migrants prefer renting more spacious housing with better amenities and living conditions, which would bring about higher rental housing stress among high-skilled migrants $[58,59]$. Moreover, the $\beta$ values of education levels in the two regression models are reported as 0.160 and 0.179 , respectively, which are much greater than other factors (except for income and industry type). This explains why we should pay more attention to the high- and low-skilled divide in migrant rental housing stress in the following regional heterogeneity studies.

Secondly, employment factors considerably affect migrant rental housing stress, as reported in Table 3. Migrants engaged in the service industry (producer service, public service, and consumer service) have reported significantly higher rental housing stress than those employed in secondary industries. This result indicates that manufacturing workers may have a collective consumption of cheap rental housing, such as the dormitory-like co-renting (qunzu) strategy that can lower individual housing costs [60]. It is also probable that migrant workers engaged in services economies earn higher wages to pay for more spacious and better conditioned rental housing [106]. It is also found that the migrants employed in the collective enterprises are faced with a heavier rental housing stress than those in the private enterprises. Apparently, state-owned enterprises and foreign enterprises can provide a more stable job and a more comprehensive social welfare, including the Housing Provident Fund, which can ease housing stress to some extent. It is also reported that the staff who have access to the social security system normally have a steady income, and they can enjoy housing subsidies and housing funds at the same time [70]. This would lower the housing stress of migrant workers who are inside the social security system in the host cities. As proof, it is suggested in the regression results that the rental housing stress of migrants who enjoy the Housing Provident Fund is significantly lower, which is also in line with the above analysis results. Those with an unstable job or an informal labor contract have lower rental housing stress, because of their preference for the minimalization of housing consumption in the host cities under a very tight budget and at a transitory migration stage. This is true among the migrants who do not intend to stay in the cities permanently [103]. The analysis results are basically similar to one another across different regions in China, involving the East China, Central 
China, West China, and Northeast China. This indicates the similar distribution of migrant rental housing pressure on the socio-economic ladder across the different regions in China, despite of the vast regional inequalities across mainland China $[109,110]$.

\subsection{Comparing and Explaining the High-Rent-Stress Agglomeration: High- vs. Low-Skilled Migrants}

\subsubsection{The Spatiality of High-Rent-Stress Migrants: High- vs. Low-Skilled Migrants}

As reported in Table 3, the education level of migrants has a much greater influence on migrant rent stress than other factors (except for income and industry type). Based on the research results of the National Development and Reform Commission, we regard migrants with a rent-income ratio above 25 percent as the group with high rental housing pressure [111]. This threshold at 25 percent is lower than the 30 percent standard, which was set and widely used in previous studies on Europe and North America $[79,80,83,84]$, but this is more appropriate in the context of transitional China considering the huge areal heterogeneity across different regions and administrative levels. In this study, we calculate the spatial clustering and dispersion of the numbers of high-rent-stress migrants (whose rent-income ratio is above 25 percent) as an alternative index in order to measure the spatiality of rental housing stress beyond Section 4.1. At the regional level, the geographical distribution of the high-rent-stress migrants can directly reflect an overall socio-economic situation of regional immigration. To be more specific, the next analysis includes two research objectives: (a) the regional heterogeneity of high-rent-stress migrants, as compared between high- and low-skilled migrants; and (b) the mechanism explaining the above spatial distribution of the different high-rent-stress migrant groups.

The Moran's I value of high-rent-stress high-skilled migrants is $0.17(p=0.05)$, which indicates a medium level of positive spatial agglomeration across the prefecture-level cities and above of mainland China. As shown in Figure 3a, the high stress group of high-skilled migrants is mainly distributed in six top-ranked Chinese coastal cities including Beijing, Shanghai, Guangzhou, Shenzhen, Suzhou, and Hangzhou. These cities are all the leaders of the three largest coastal urban agglomerations (Beijing-Tianjin-Hebei, the Yangtze River Delta, and the Pearl River Delta), with a rapid rise of advanced producer service firms (including the Zhongguancun High-Tech Park in Beijing, the Zhangjiang High-Tech Park in Shanghai, the Suzhou Industrial Park, Alibaba in Hangzhou, Tencent, the Huawei and Beijing Genomics Institute located in Shenzhen) [112,113]. The internet economies, artificial intelligence (AI) industries, and high-tech development in the areas of bioscience and environment technologies in the top-tiered cities have attracted millions of talents to work, live, and settle down there [114]. This explains the reason why a large number of skilled migrants intend to congregate in the big cities, with technology-intensive industries together with continuous sectoral upgrading initiatives. Moreover, till now, more comprehensive city planning has been made and implemented in these first-tier cities to attract and serve talents. The planning and policies cover a wide range of areas including intelligent city, cyber city, green city, high-quality shopping, and recreational spaces. $[23,59,114]$. Some housing-related welfare policies are also supportive of the "talent plan" in these cities, such as the talent apartment schemes in Beijing, Suzhou, and Shenzhen [115]. By using Getis-Ord Gi* in ArcGIS which is derived from Arthur Getis in San Diego and J. Keith Ord in Washington D.C. in the USA, we identified the local spatial clusters of high-skilled high-rent-stress migrants. In the Figure $3 b$, it can be seen that the hot spots are the six cities mentioned previously: Beijing, Shanghai, Guangzhou, Shenzhen, Suzhou, and Hangzhou. 


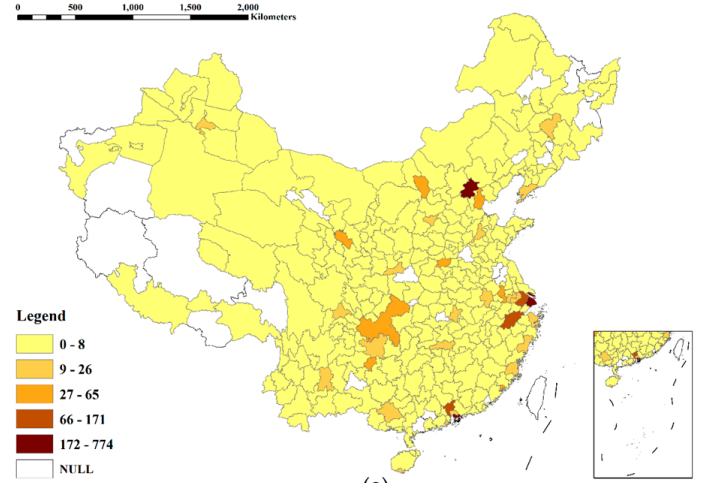

(a)

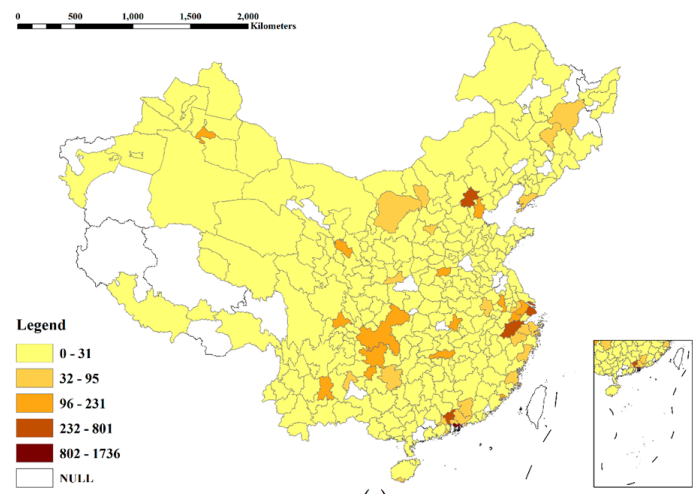

(c)
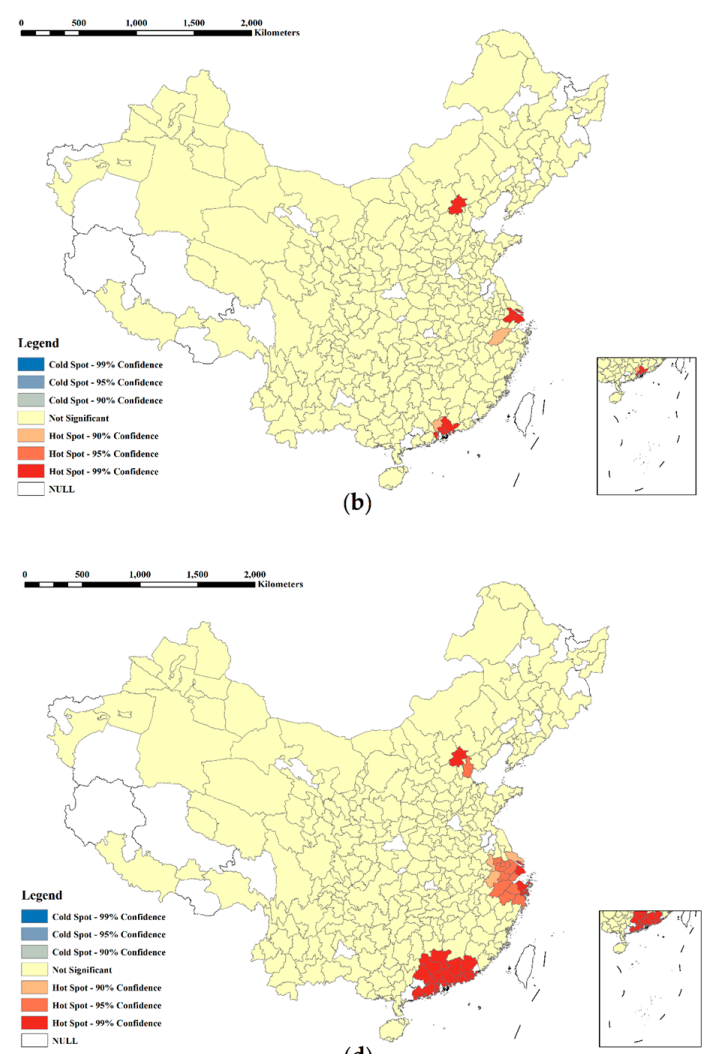

(d)

Figure 3. Spatiality of high-rent-stress migrants in urban China: (a) high-skilled migrants with high rent stress; (b) hot spot analysis of high-skilled high-rent-stress migrants; (c) low-skilled migrants with high rent stress; (d) hot spot analysis of low-skilled high-rent-stress migrants.

The spatial distribution of low-skilled high-rent-stress migrants tends to be centralized as well but sprawling a bit towards the vast surrounding areas of the above regional center cities. The Moran's $I$ value of low-skilled migrants of high stress is $0.27(p=0.001)$, which indicates that there is the positive spatial autocorrelation on the national scale. As shown in Figure 3c, the high-stress group of low-skilled migrants is mainly distributed in the main urban agglomerations and the provincial capital cities. In coastal China, the urban agglomerations of Beijing-Tianjin-Hebei (Beijing, Tianjin), the Yangtze River Delta (Shanghai, Suzhou, Hangzhou) and the Pearl River Delta (Shenzhen, Guangzhou, Dongguan) have significant geographical, industrial and policy advantages $[112,113]$. The three urban clusters, which are the opening windows of China, are the most competitive economic zones in the whole country and have led national economic and technological development and also attracted a large floating population. In recent years in southwest China, the Chengdu-Chongqing urban agglomeration represents the leading cities of the opening-up and development of western cities in China, and is also an important modern innovation industrial base [116]. In Central and West China, low-skilled high-rent-stress migrants are normally concentrated in provincial capital cities such as Wuhan, Taiyuan, Zhengzhou, and Changsha. From an areal perspective, migrant rental housing stress is more likely to be found in the metropolitan areas. More recently, however, some attention has been directed towards the movement of low-income earners to non-metropolitan areas, partially due to the unaffordability of rising housing rentals and living costs in the above metropolitan areas [117]. This is particularly true for low-skilled migrants who are worse educated, insufficiently trained, and thus hardly adaptive to the rapidly changing metropolitan industrial structure and labor market [69]. Therefore, compared with a tightly-clustered pattern of the skilled group, the unskilled migrants tend to be congregated in both the core cities and their surrounding areas, forming a localized agglomeration and spillover to the surrounding areas of the urban clusters in China today (see Figure 3c). 
We further look into the spatial clusters of low-skilled high-rent-stress migrants using hot spot analysis in ArcGIS. As shown in Figure 3d, the hot spots of low-skilled high-rent-stress migrants are found to be mainly distributed in three urban agglomerations (Beijing-Tianjin-Hebei, the Yangtze River Delta, and the Pearl River Delta). In the Beijing-Tianjin-Hebei urban agglomeration, Beijing and Tianjin, as the provincial level municipalities, possess better basic conditions especially in policy support. The disparity in the regional economy in the Beijing-Tianjin-Hebei urban agglomeration explains the flow of migrants to Beijing and Tianjin, leading to an uneven distribution of the labor force in the whole region [118]. Housing rents in Beijing and Tianjin are thus rising fast, resulting in the high rent stress of migrants, especially low-skilled migrants [119-121]. In the Yangtze River Delta urban agglomeration, the hot spot values of low-skilled migrants with high rent stress are declining from the core to the periphery. Because the Yangtze River Delta is one of the leaders of innovation in China, many high-tech industries are seated in the major cities of the Yangtze River Delta including Shanghai, Suzhou, Hangzhou, Ningbo and others [122-124]. The rental and living costs in these cities are also relatively high compared to other regions in urban China. Owing to a deeper integration of secondary and tertiary industries in the Pearl River Delta in recent years, the rapid industrial upgrading has facilitated a more flexible mobility of migrant workers across the different cities, which assume the complementary functions in the urban cluster in the Pearl River Delta [107]. These advantages have strongly attracted millions of low-skilled migrants to move in and settle down, but these low-skilled migrants have to bear a high rental housing stress against the background of a serious housing bubble [125].

\subsubsection{Mechanism Explaining the High- vs. Low-Skilled Gap in Spatiality of High-Rent-Stress Migrants}

With sustained progress, many evolved spatial models have emerged in recent years. A Bayesian approach to estimating spatial autoregressive models based on Gibbs sampling (sometimes referring to as the Markov Chain Monte Carlo sampling) was introduced in LeSage's studies [126]. Bayesian estimation allows for non-constant variance over space taking an unspecified form and outliers in the sample data. By using a Bayesian model, LeSage explored the relationship between neighborhood crime incidents and household income, as well as house values, and he also studied the influences of education, home ownership, and income on the voting age population [126]. This study was based on a data sample containing voter turn-out rates in 3107 U.S. counties during the 1980 presidential election $[126,127]$. But the Bayesian approach is mainly applicable to a non-normal distribution, therefore not fully suitable for our research. In addition, three types of spatial models have received considerably more attention than those in previous periods, namely, spatial panel models, models for spatial latent variables, and models for flows [128]. General model specifications and estimation strategies (both the maximum likelihood model and the generalized method of moments model) are proposed here. For example, Elhorst had used a mixed model of random coefficients for regional-level variables and fixed coefficients for national-level variables to investigate the causes of variation in regional labor force participation rates in a cross-country perspective [129]. Elhorst suggested that the hypotheses that regional participation rates in the EU were determined by a common structure and that labor force participation could be encouraged by a common policy must be strongly rejected [129].

Studies of spatial heterogeneity are often based on a variety of conventional regression models in the recent years, such as the ordinary least square (OLS), the generalized method of moments (GMM), and the maximum likelihood (ML) models [88]. For instance, Wang's study identified the positive effects exerted by the proportion of renters, the floating population, wage levels, the cost of land, the housing market and city service levels on housing prices, and the negative influence exerted by living space by using these conventional spatial regression techniques (including SLM and SEM) [88]. Chen confirmed that population growth and economic advancement exerted a considerable influence on socioeconomic development, thereby affecting the change of ecosystem service value (ESV) based on the study of the impact of human activities on land use change and consequent dynamics of ESV by using spatial lag and spatial error models [130]. Furthermore, Zhang suggested that all air 
pollution emissions in China's 31 provinces had significant spatial dependence and strong spillover effects at different significance levels by using spatial lag models [131]. Given that many scholars conduct the similar research on migration, housing prices, and other socioeconomic problems based on these conventional spatial regression models $[88,130,131]$, we also choose the ordinary least square (OLS), the spatial lag (SLM) and the spatial error (SEM) models in this study to look into migrant rent affordable stress issues in urban China. In this paper, we analyze the driving factors that can interpret the variance of the high- and low-skilled migrants in terms of the geographic distribution of high-rent-stress samples (rent-income ratios above 25 percent), by using the ordinary least square (OLS), the spatial lag (SLM) and the spatial error (SEM) models. By using Breusch-Pagan test, the heteroscedasticities in models are proved to be significant, so the spatial regression models (SRM) are regarded better for the research. In conducting the GeoDa, it is advised to use AIC (Akaike information criterion) as a measure of model fit where the smaller AIC indicates a better fit. It is found that SEM is more appropriate in the regression model on: (a) high-skilled high-rent-stress migrants $\left(R^{2}=0.89\right.$, $\mathrm{AIC}=3000.73)$; (b) the low-skilled high-rent-stress migrants $\left(R^{2}=0.70, \mathrm{AIC}=3825.92\right)$; and (c) all the samples of high-rent-stress migrants at a national scale $\left(R^{2}=0.63\right.$, AIC $\left.=3501.82\right)$. The detailed results are listed in Table 4.

According to the above regression results, we can see that EDU, PPS, and HP positively and significantly influence the high-skilled and low-skilled high-rent-stress migrants, while SAT is a negative factor for high- and low-skilled migrants. GDP is an inhibitory factor on high-skilled high-rent-stress migrants but it is insignificant; while GDP is a positive and marginally significant indicator for low-skilled high-rent-stress migrants. FAI has a significantly negative impact on high-skilled high-rent-stress migrants, but also exerts a significantly positive impact on the total high-rent-stress migrants. Besides, POT is an insignificant indicator on all the three groups. Based on the above main findings, we have found the main impact factors on the spatial congregation of highand low-skilled high-rent-stress migrants. 
Table 4. Spatial regression analysis on high-rent-stress migrants: high- and low-skilled migrants and the total.

\begin{tabular}{|c|c|c|c|c|c|c|c|c|c|}
\hline \multirow{2}{*}{ Variables } & \multicolumn{3}{|c|}{ High-Skilled } & \multicolumn{3}{|c|}{ Low-Skilled } & \multicolumn{3}{|c|}{ Total } \\
\hline & OLS & SLM & SEM & OLS & SLM & SEM & OLS & SLM & SEM \\
\hline Constant & -2.674 & -2.439 & -2.575 & -12.578 & -10.416 & -11.249 & 2.353 & 6.824 & -4.305 \\
\hline GDP & -0.007 & -0.007 & -0.008 & $0.059^{* *}$ & $0.060^{* *}$ & $0.055^{*}$ & $0.065^{* * *}$ & $0.066^{* * *}$ & $0.092^{* * *}$ \\
\hline SAT & $-0.125^{* * *}$ & $-0.126^{* * *}$ & $-0.127 * * *$ & $-0.610^{* * *}$ & $-0.619^{* * *}$ & $-0.614^{* * *}$ & $-0.170 * *$ & $-0.175^{* *}$ & -0.087 \\
\hline FAI & $-0.045^{* * *}$ & $-0.045^{* * *}$ & $-0.045^{* * *}$ & 0.048 & 0.048 & 0.046 & $0.047^{* *}$ & $0.047^{* *}$ & $0.045^{* *}$ \\
\hline POT & -0.072 & $-0.074 *$ & -0.071 & 0.037 & 0.025 & 0.041 & $0.192 *$ & $0.195^{* *}$ & 0.056 \\
\hline PPS & $0.195^{* *}$ & $0.195^{* * *}$ & $0.196^{* * *}$ & $0.063^{* * *}$ & $0.061^{* * *}$ & $0.068^{* * *}$ & $0.077^{* * *}$ & $0.076^{* * *}$ & $0.041^{* * *}$ \\
\hline EDU & $0.003^{* * *}$ & $0.004^{* * *}$ & $0.004^{* * *}$ & $0.035^{* * *}$ & $0.036^{* * *}$ & $0.037^{* * *}$ & $0.015^{* * *}$ & $0.016^{* * *}$ & $0.016^{* *}$ \\
\hline HP & $0.301^{* * *}$ & $0.302 * * *$ & $0.296^{* * *}$ & $0.846^{* * *}$ & $0.833^{* * *}$ & $0.812 * * *$ & -0.127 & -0.141 & -0.047 \\
\hline Lag coeff (rho/lambda) & & -0.021 & -0.047 & & -0.044 & -0.053 & & -0.141 & 0.367 \\
\hline $\operatorname{Adj} R^{2}$ & 0.8897 & 0.8898 & 0.8899 & 0.6982 & 0.7000 & 0.6990 & 0.6075 & 0.6165 & 0.6307 \\
\hline$p$-value & 0.000 & 0.000 & 0.000 & 0.000 & 0.000 & 0.000 & 0.000 & 0.000 & 0.000 \\
\hline Likelihood ratio test & & 0.489 & 0.478 & & 1.919 & 0.809 & & $6.706^{* *}$ & $11.011^{* * *}$ \\
\hline Breuch-Pagan test & $2841.477^{* * *}$ & $2784.189^{* * *}$ & $2785.938^{* * *}$ & $16601.000^{* * *}$ & $16253.707^{* * *}$ & $16409.344^{* * *}$ & $442.757^{* * *}$ & $403.648^{* * *}$ & $325.638^{* * *}$ \\
\hline Sigma-square & 330.12 & 321.93 & 321.83 & 4006.73 & 3890.02 & 3901.99 & 1604.48 & 1530.97 & 1474.31 \\
\hline Log Likelihood & -1477.25 & -1477.01 & -1477.02 & -1905.37 & -1904.41 & -1904.96 & -1748.41 & -1745.06 & -1742.90 \\
\hline AIC & 3001.21 & 3006.96 & 3000.73 & 3826.73 & 3826.81 & 3825.92 & 3512.83 & 3508.12 & 3501.82 \\
\hline
\end{tabular}


Firstly, the economic factors have different influences on the different sub-groups. The negative correlation between GDP and the number of high-skilled high-rent-stress migrants may display that the high-skilled migrants are welcome in the destination cities because of their rich knowledge and professional skills. Most of the high-skilled migrants could find better jobs and enjoy policy subsidies such as housing allowances and talent housing than low-skilled migrants [30-33]. As for low-skilled migrants, they mostly have low pay and unstable jobs that can hardly afford the high rentals in the advanced economies, thus displaying a positive and marginally significant correlation between GDP and the scale of low-skilled high-rent-stress migrants $[69,70]$. SAT has a negative correlation with highand low-skilled high-rent-stress migrants, indicating that the higher non-agricultural outputs in the destination cities can predict a lower probability of the high-rent-stress clustering [104]. Table 4 also shows that fixed asset investment (FAI) plays an important role to attract investments and migrant workers, but would not beef up the rental housing stress faced by high-skilled migrants, but can bring about rental pressure among all the migrant groups.

Secondly, POT is an insignificant indicator on all the three groups, displaying that the proportion of tenants has the insignificant correlation with the congregation of the high-rent-stress migrants. The proportion of producer services (PPS) in urban jobs is proved to be a significant and positive factor for all the three groups of high-rent-stress migrants. In the knowledge economy, the process of marketization, industrialization and urbanization is accelerated largely by the promoting of the tertiary industry, especially the modern and advanced producer services in the great metropolitan areas [105]. The congregation of advanced producer services also calls for highly skilled migrant workers whose migration is driven by their pursuits of urban amenities. It is therefore found that the spatial clustering of advanced service economies is accompanied by a large congregation of high-rent-stress migrant workers (including high- and low-skilled and total high-rent-stress migrants).

Thirdly, the factor of education level (EDU) is greatly significant to predict the occurrence of high-rent-stress migrant clustering in urban areas, indicating a strong correlation between quality educational resources and higher rental expenses in migrant households. This result also indicates that the move to urban areas of migrants is motivated largely by the pursuits of the better educational resources in the destination cities [115]. Besides, housing prices (HPs) have a significant effect on the spatial distribution of high- and low-skilled high-stress migrants. A higher housing price would bring about a higher rent in the local housing market, and obviously along with the high rent stress among migrants. Furthermore, in high- and low-skilled high-rent-stress migrant regression models, the coefficients of the HP indicator are reported to be 0.296 and 0.812 for high- and low-skilled high-rent-stress migrants, respectively. This result shows that low-skilled migrants would be more voluntary and sensitive to the speculative housing market than high-skilled migrants in the face of high rents.

\section{Conclusions}

In the current era of the knowledge economy, problems with rental housing unaffordability in metropolitan areas have attracted much attention in the different parts of the world [55,56,58]. But few studies have been conducted to examine the rental housing pressure faced by low-wage migrants and talents in urban China today. Given the importance of this problem, we analyze the sociality and spatiality of migrant rental housing stress across prefecture-level cities and above, as well as the patterns and dynamics of high-rent-stress migrant clustering across high- and low-skilled groups, respectively. The data used in this article is derived from China's Migrant Dynamics Monitoring Survey (MDMS) in 2016. We employed the Moran's I and Getis-Ord Gi* to attest the spatial heterogeneity of migrant rent stress at the prefectural scale in China. It is found that the migrants would bear the heavier rent pressure if they move to the core cities in the urban agglomerations and the provincial capital cities in East and Central China. North and Southwest China has witnessed a high rent-income ratio of the migrant households. Interestingly, it is shown in the OLS results that the educational 
background of migrant workers is the significant and most powerful indicator (besides income and industry type) in predicting a high rental stress for migrants at the prefectural city level.

Owing to the importance of educational background in predicting high rent pressure events, this paper continues to study the spatial variance of the high-rent-stress migrants across their high- and low-skilled binary categories. It is found that high-skilled high-rent-stress migrants tend to congregate in the six top-tier cities in China that are the growth engines of whole country, such as Beijing, Shanghai, Guangzhou, Shenzhen, Suzhou, and Hangzhou. The low-skilled high-rent-stress migrants have clustered not only in these core cities of the urban agglomerations (such as Beijing-Tianjin-Hebei, the Yangtze River Delta, and the Pearl River Delta) and the provincial capital cities, but also spillovered into the hinterlands surrounding these growth engines. Such a distinct spatial pattern of high-rent-stress migrants across high- and low-skilled categories can provide more solid proof for more targeted housing policy-making in the different parts of the urban cluster areas in China.

This paper also interpreted the above spatial heterogeneity of high-rent-stress migrants across highand low-skilled categories by using OLS and SRM. It is found that, for high-skilled high-rent-stress migrants, the booming advanced producer services economy, the quality educational resources, together with a high housing price are the three significant and positive indicators predicting a cluster of them; while high non-agricultural outputs and fixed asset investment are significant but negative indicators predicting a spatial congregation of them. For low-skilled high-rent-stress migrants, a more advanced economy, educational resources and higher housing price are the positive and significant factors in forming their spatial clustering; and non-agricultural share in GDP is also a negative factor here. The coefficients in the regression model also show that the low-skilled high-rent-stress migrants are more sensitive and vulnerable to the high rentals than high-skilled migrants (see Table 4). These results can tell the different rental pressure patterns between high- and low-skilled migrants in urban China $[65,69,70]$.

There are some policy suggestions based on our main findings. The rental unaffordability issue is a big challenge at the current stage of the New Urbanization Strategy. Firstly, local governments should actively beef up the housing supply system and standardize the rental housing market that are open to the migrant workers. Secondly, as shown in Figure 3, high-skilled high-rent-stress migrants have been mainly distributed in the high ranked cities including Beijing, Shanghai, Shenzhen, Guangzhou, Suzhou, and Hangzhou. High-skilled migrants may place more importance on amenity-related issues [57]. According to the main findings as shown above, big cities are supposed to implement a more inclusive public housing policy to ensure that high-skilled migrants enjoy their welfare. At the same time, low-skilled migrants are concentrated in top-tier cities and their surrounding cities, so the local government should carry out public rental housing policies for the low-skilled high-rent-stress migrants as well, in order to guarantee a multi-level labor force supply for the interconnected industrial network between core and peripheral cities in the main urban clusters. In addition, in the current innovation economy, local governments should pay more attention to the amenity-driven mobility of high-skilled migrants and provide friendly policies to attract them. Our study also provides a guiding implication on guaranteeing social justice in the rapid urbanization stage happening in China today.

Author Contributions: All the authors have contributed in the writing of this article. T.L. conducted the data analysis and the drafting of the article. R.L. administered this research and did the editorial work on this paper. W.Q. provided the geographical database for this study and check the model items.

Funding: This research was funded by a grant from the Youth Foundation for National Natural Science Foundation of China (NSFC project number: 41701188) and a grant from the Youth Foundation for Humanities and Social Sciences, Ministry of Education of China (Project number: 16YJCZH060; project title: socio-spatial mobility and spatial justice of migrant workers-a case study on Beijing, China), and a grant from the Social Science Foundation of Beijing Municipal Education Commission (project title: tempo-spatial pattern and policy implication of migrant housing choice stratification).

Conflicts of Interest: The authors declare no conflicts of interest. 


\section{References}

1. Florida, R. The creative class and economic development. Econ. Dev. Q. 2014, 28, 196-205. [CrossRef]

2. Florida, R. Where the skills are. Atlantic. October 2011. Available online: https://www.theatlantic.com/ magazine/archive/2011/10/where-the-skills-are/308628/ (accessed on 3 August 2019).

3. Florida, R. More losers than winners in America's new economic geography. Citylab. 30 January 2013. Available online: www.citylab.com/work/2013/01/more-losers-winners-americas-new-economicgeography/ 4465/ (accessed on 3 August 2019).

4. Florida, R. Cities and the creative class. City Community 2003, 2, 3-19. [CrossRef]

5. Dokko, J.; Doyle, B.M. Monetary policy and the global housing bubble. Econ. Policy 2011, 22, $233-283$. [CrossRef]

6. United Nations. The 2015 Revision of World Population Prospects; United Nations: New York, NY, USA, 2015.

7. Sohu. Projections for China's Rental Housing Market. 2018. Available online: https://house.focus.cn/zixun/ 4ce70da0536e7259.html (accessed on 3 August 2019).

8. Lin, L.Y.; Zhu, Y. The diverse housing needs of rural to urban migrants and policy responses in China: Insights from a survey in Fuzhou. IDS Bull. 2010, 41, 12-21. [CrossRef]

9. Montgomery, J.L. The inheritance of inequality: Hukou and related barriers to compulsory education for China's migrant children. Wash. Int. Law J. 2012, 21, 591.

10. Liu, R. Spatial Mobility of Migrant Workers in Beijing, China; Springer International Publishing: Cham, Switzerland, 2015.

11. Wang, Y.P.; Wang, Y.; Wu, J. Housing migrant workers in rapidly urbanizing regions: A study of the Chinese model in Shenzhen. Hous. Stud. 2010, 25, 83-100. [CrossRef]

12. Liu, R.; Wong, T.C. Urban village redevelopment in Beijing: The state-dominated formalization of informal housing. Cities 2018, 72, 160-172. [CrossRef]

13. Liu, R.; Wong, T.C. The allocation and misallocation of economic housing in Beijing: Target groups versus market forces. Habitat Int. 2015, 49, 303-315. [CrossRef]

14. Zhu, Y.; Lin, L.Y.; Chen, J. The extent of in situ urbanization in China's county areas: The case of Fujian Province. China Perspect. 2013, 3, 43-52.

15. Liu, Z.L.; Wang, Y.J.; Tao, R. Social capital and migrant housing experiences in urban China: A structural equation modeling analysis. Hous. Stud. 2013, 28, 1155-1174. [CrossRef]

16. Zhou, Y.; Guo, Y.; Liu, Y.S. High-level talent flow and its influence on regional unbalanced development in China. Appl. Geogr. 2018, 91, 89-98. [CrossRef]

17. Li, T.Z.; Liu, R. Identification and spatial agglomeration of high rent stress migrants in China. In Proceedings of the 2019 Demographic Geography Conference in China, Beijing, China, 22-23 June 2019.

18. Huang, S.; Hou, J.W.; Sun, L.; Dou, D.H.; Liu, X.; Zhang, H.C. The effects of objective and subjective socioeconomic status on subjective well-being among rural-to-urban migrants in China: The moderating role of subjective social mobility. Orig. Res. 2017, 8, 819. [CrossRef] [PubMed]

19. Liu, X.; Da, W.Z.; Martin, G.F.; Liu, K.Y. Regional income mobility in large cities throughout China. Appl. Econ. Lett. 2019, 26, 1322-1327. [CrossRef]

20. Sun, D.Q.; Zhou, L.; Li, Y.; Liu, H.M.; Shen, X.Y.; Wang, Z.D.; Wang, X. New-type urbanization in China: Predicted trends and investment demand for 2015-2030. J. Geogr. Sci. 2017, 27, 943-966. [CrossRef]

21. He, S. The creative spatio-temporal fix: Creative and cultural industries development in Shanghai, China. Geoforum 2017. [CrossRef]

22. Zhao, L.Q.; Liu, S.Y.; Zhang, W. New trends in internal migration in China: Profiles of the new-generation migrants. China World Econ. 2018, 26, 18-41. [CrossRef]

23. Cui, C.; Geertman, S.; Hooimeijer, P. The intra-urban distribution of skilled migrants: Case studies of Shanghai and Nanjing. Habitat Int. 2014, 44, 1-10. [CrossRef]

24. Chan, K.W. China's urbanization 2020: A new blueprint and direction. Eurasian Geogr. Econ. 2014, 55, 1-9. [CrossRef]

25. Zhang, J.P.; Wang, R.; Lu, C. A quantitative analysis of Hukou reform in Chinese cities: 2000-2016. Growth Chance 2018, 50, 201-221. [CrossRef]

26. Gomez, R.; Lamb, D. Demographic origins of the great recession: Implications for China. China World Econ. 2013, 21, 97-118. [CrossRef] 
27. Mai, Y.H.; Peng, X.J.; Chen, W. How fast is population ageing in China? Asian Popul. Stud. 2013, 9, $216-239$. [CrossRef]

28. Yenilmez, M.I. Economic and social consequences of population aging the dilemmas and opportunities in the twenty-first century. Appl. Res. Qual. Life 2015, 10, 735-752. [CrossRef]

29. Wu, P.K.; Wu, C.; Wu, Y. Reforming path of China's fertility policy in stabilizing demographic dividends perspective. Soc. Indic. Res. 2018, 137, 1225-1243. [CrossRef]

30. Golley, J.; Tyers, R. Demographic dividends, dependencies, and economic growth in China and India. Asian Econ. Pap. 2012, 11, 1-26. [CrossRef]

31. Chang, X.Y.; Shi, Y. The economic study on effects of Chinese economic growth of human capital. Inf. Technol. Quant. Manag. 2016, 91, 1096-1105. [CrossRef]

32. Souhu. The Hukou Policy in Shanghai. 2017. Available online: http://www.sohu.com/a/223056989_769542 (accessed on 3 August 2019).

33. Souhu. The Interpretation of Talent Policies in Wuhan. 2018. Available online: https://wh.focus.cn/zixun/ aab1a24d08bbfd7f.html (accessed on 3 August 2019).

34. Zhou, J.; Musterd, S. Housing preference and access to public rental housing among migrants in Chongqing, China. Habitant Int. 2018, 79, 42-50. [CrossRef]

35. Akbari, A.H.; Aydede, Y. Effects of immigration on house prices in Canada. Appl. Econ. 2012, 44, 1645-1658. [CrossRef]

36. Gonzalez, L.; Ortega, F. Immigration and housing booms: Evidence from Spain. J. Reg. Sci. 2013, 53, 37-59. [CrossRef]

37. Saiz, A. Immigration and housing rents in American cities. J. Urban Econ. 2007, 61, 345-371. [CrossRef]

38. Ottaviano, G.I.P.; Peri, G. Immigration and National Wages: Clarifying the Theory and the Empirics; Social Science Electronic Publishing: Rochester, NY, USA, 2008; Volume 43, p. 1741.

39. Bohn, S.; Lofstrom, M.; Raphael, S. Did the 2007 legal Arizona workers act reduce the State's unauthorized immigrant population? Rev. Econ. Stat. 2011, 96, 258-269. [CrossRef]

40. Arbaci, S.; Malheiros, J. De-segregation, peripheralization and the social exclusion of immigrants: Southern European cities in the 1990s. J. Ethn. Migr. Stud. 2010, 36, 227-255. [CrossRef]

41. Saiz, A. The geographic determinants of housing supply. Q. J. Econ. 2010, 125, 1253-1296. [CrossRef]

42. Glaeser, E.L.; Gyourko, J.; Saiz, A. Housing supply and housing bubbles. J. Urban Econ. 2008, 64, $198-217$. [CrossRef]

43. Saiz, A. Room in the kitchen for the melting pot: Immigration and rental prices. Rev. Econ. Stat. 2003, 85, 502-521. [CrossRef]

44. Antoniucci, V.; Marella, G. Immigrants and the city: The relevance of immigration on housing price gradient. Buildings 2017, 7, 91. [CrossRef]

45. Forte, F.; Antoniucci, V.; Paola, P.D. Immigration and the housing market: The case of Castel Volturno, in Campania Region, Italy. Sustainability 2018, 10, 343. [CrossRef]

46. Jacobs, J. The Death and Life of Great American Cities; Random House: New York, NY, USA, 1961.

47. Jacobs, J. The Economy of Cities; Random House: New York, NY, USA, 1969.

48. Ullman, E.L. Regional development and the geography of concentration. Pap. Proc. Reg. Sci. Assoc. 1958, 4, 179-198. [CrossRef]

49. Florida, R. Talent, technology, and tolerance in Canadian regional development. Can. Geogr. 2010, 54, 277-304. [CrossRef]

50. Florida, R. The economic geography of talent. Ann. Assoc. Am. Geogr. 2002, 92, 743-755. [CrossRef]

51. Berman, E.; Bound, J.; Griliches, Z. Changes in the demand for skilled labor within U.S. manufacturing: Evidence from the annual survey of manufacturers. Q. J. Econ. 1994, 109, 367-397. [CrossRef]

52. Tammaru, T.; Stromgren, M.; van Ham, M.; Danzer, A.M. Relations between residential and workplace segregation among newly arrived immigrant men and women. Cities 2016, 59, 131-138. [CrossRef]

53. Pigott, C.A. China in the World Economy: The Domestic Policy Challenges; OECD Publishing: Paris, France, 2002.

54. Li, Z.G. Housing conditions, patterns and mechanisms of second-generation migrants in urban China: A case study of six large cities. Acta Geogr. Sin. 2012, 67, 189-200.

55. Lee, P.; Murie, A. The role of housing in delivering a knowledge economy. Built Environ. 2004, 30, $235-245$. [CrossRef]

56. Berry, M. Melbourne-Is there life after Florida? Urban Policy Res. 2005, 23, 381-392. [CrossRef] 
57. Liu, Y.; Shen, J.F. Jobs or amenities? Location choices of interprovincial skilled migrants in China, 2000-2005. Popul. Space Place 2014, 20, 592-605. [CrossRef]

58. Tomaney, J.; Bradley, D. The economic role of mobile professional and creative workers and their housing and residential preferences, evidence from North East England. Town Plan. Rev. 2007, 78, 511-530. [CrossRef]

59. Cui, C.; Geertman, S.; Hooimeijer, P. Access to homeownership in urban China: A comparison between skilled migrants and skilled locals in Nanjing. Cities 2016, 50, 188-196. [CrossRef]

60. He, S.J.; Liu, Y.T.; Wu, F.L.; Webster, C. Social groups and housing differentiation in China's urban villages: An institutional interpretation. Hous. Stud. 2010, 25, 671-691. [CrossRef]

61. Li, Z.G.; Wu, F.L. Tenure-based residential segregation in post-reform Chinese cities: A case study of Shanghai. Trans. Inst. Br. Geogr. 2008, 33, 404-419. [CrossRef]

62. Li, S.M.; Liu, Y. Land use, mobility and accessibility in dualistic urban China: A case study of Guangzhou. Cities 2017, 71, 59-69. [CrossRef]

63. Sun, M.J.; Fan, C.C. China's permanent and temporary migrants: Differentials and changes, 1990-2000. Prof. Geogr. 2011, 63, 92-112. [CrossRef]

64. Mooney, J.D. Housing segregation, negro employment, and metropolitan decentralization. Q. J. Econ. 1969, 83, 299-311. [CrossRef]

65. Clemens, J.; Wither, M. The Minimum Wage and the Great Recession: Evidence of Effects on the Employment and Income Trajectories of Low-Skilled Workers; Social Science Electronic Publishing: Rochester, NY, USA, 2014.

66. Grogger, J.; Hanson, G.H. Income maximization and the selection and sorting of international migrants. J. Dev. Econ. 2011, 95, 42-57. [CrossRef]

67. Liu, R.; Wong, T.C.; Liu, S.H. Low-wage migrants in northwestern Beijing, China: The hikers in the urbanization and growth process. Asia Pac. Viewp. 2013, 54, 352-371. [CrossRef]

68. Wong, T.C.; Liu, R. Developmental urbanism, city image branding and the "right to the city" in transitional China. Urban Policy Res. 2017, 35, 210-223. [CrossRef]

69. Hainmueller, J.; Hiscox, M.J. Attitudes toward highly skilled and low-skilled immigration: Evidence from a survey experiment. Am. Political Sci. Rev. 2010, 104, 61-84. [CrossRef]

70. Huang, Y.Q. Low-income housing in Chinese cities: Policies and practices. China Q. 2012, 212, 941-964. [CrossRef]

71. Ye, J.P.; Wu, Z.H. Urban housing policy in China in the macro-regulation period 2004-2007. Urban Policy Res. 2008, 26, 283-295. [CrossRef]

72. The National Health and Family Planning Commission in China. 2015 of China's Migrant Dynamics Monitoring Survey (MDMS); The National Health and Family Planning Commission in China: Beijing, China, 2016.

73. Liu, Z.; Liu, S.H. Polycentric development and the role of urban polycentric planning in China's mega cities: An examination of Beijing's metropolitan area. Sustainability 2018, 10, 1588. [CrossRef]

74. Zheng, S.Q.; Long, F.J.; Fan, C.C.; Gu, Y.Z. Urban villages in China: A 2008 survey of migrant settlement in Beijing. Eurasian Geogr. Econ. 2009, 50, 425-446. [CrossRef]

75. Logan, J.R.; Fang, Y.; Zhang, Z. Access to housing in urban China. Int. J. Urban Reg. Res. 2009, 33, 914-935. [CrossRef] [PubMed]

76. Wang, Y.P.; Murie, A.; Cheng, J. The maturation of the neo-liberal housing market in urban China. Hous. Stud. 2012, 27, 343-359. [CrossRef]

77. Wu, X. Urban Spatial Restructuring and Housing Development in Shanghai 1990-2002. Ph.D. Thesis, National University of Singapore, Singapore, 2004.

78. Wu, F.; Li, Z. Sociospatial differentiation: Processes and spaces in subdistricts of Shanghai. Urban Geogr. 2005, 26, 137-166. [CrossRef]

79. Wilson, W.J.; Aponte, R. Urban poverty. Annu. Rev. Sociol. 1985, 11, 231-258. [CrossRef]

80. Li, W.B. Different housing subsidies policies in America: Review of performance. Urban Dev. Stud. 2007, 3, 77-81.

81. Yu, N.P. European Social Pattern Based on European Housing Policies and Housing Market; East China Normal University Press: Shanghai, China, 2008.

82. Nelson, K.P. Whose shortage of affordable housing? Hous. Policy Debate 1994, 5, 443-458. [CrossRef]

83. Stone, M.E. What is housing affordability? The case for the residual income approach. Hous. Policy Debate 2006, 17, 151-184. [CrossRef] 
84. Bunting, T.; Walks, R.A.; Pierre, F. The uneven geography of housing affordability stress in Canadian metropolitan areas. Hous. Stud. 2004, 19, 361-393. [CrossRef]

85. Sen, A. Poverty and Famines. An Essay on Entitlement and Deprivation; Clarendon Press: Oxford, UK, 1981.

86. Kutty, N.K. A new measure of housing affordability: Estimates and analytical results. Hous. Policy Debate 2005, 16, 113-142. [CrossRef]

87. Hulchanski, J.D. The concept of housing affordability: Six contemporary uses of the housing expenditure-to-income ratio. Hous. Stud. 1995, 10, 471-491. [CrossRef]

88. Wang, Y.; Wang, S.J.; Li, G.D.; Zhang, H.; Jin, L.X. Identifying the determinants of housing prices in China using spatial regression and the geographical detector technique. Appl. Geogr. 2017, 79, 26-36. [CrossRef]

89. Cai, Z. Analyzing Measurements of Housing Affordability. Ph.D. Thesis, University of Washington, Washington, DC, USA, 2017.

90. Moore, E.; Skaburskis, A. Canada's increasing housing affordability burdens. Hous. Stud. 2004, 19, $395-413$. [CrossRef]

91. Revington, N.; Townsend, C. Market rental housing affordability and rapid transit catchments: Application of a new measure in Canada. Hous. Policy Debate 2016, 26, 864-886. [CrossRef]

92. Chen, Y.M.; Liu, X.P.; Li, X.; Liu, Y.L.; Xu, X.C. Mapping the fine-scale spatial pattern of housing rent in metropolitan area by using online rental listing and ensemble learning. Appl. Geogr. 2016, 75, 200-212. [CrossRef]

93. Li, H.; Wei, Y.D.; Wu, Y.Y. Analyzing the private rental housing market in Shanghai with open data. Land Use Policy 2019, 85, 271-284. [CrossRef]

94. Hu, L.R.; He, S.J.; Han, Z.X.; He, X.; Su, S.L.; Weng, M.; Cai, Z.L. Monitoring housing rental prices based on social media: An integrated approach of machine-learning algorithms and hedonic modeling to inform equitable housing policies. Land Use Policy 2019, 82, 657-673. [CrossRef]

95. Tobler, W. A computer movie simulating urban growth in the Detroit region. Econ. Geogr. 1970, 46, $234-240$. [CrossRef]

96. Yu, D.L.; Wei, Y.H.D. Spatial data analysis of regional development in Greater Beijing, China, in a GIS environment. Pap. Reg. Sci. 2008, 87, 97-117. [CrossRef]

97. Lin, L.Y.; Zhu, Y. Continuity and change in the transition from the first to the second generation of migrants in China: Insights from a survey in Fujian. Habitat Int. 2014, 42, 147-154.

98. Webster, C.; Wu, F.L.; Zhang, F.Z.; Chinmoy, S. Informality, property rights, and poverty in China's "favelas". World Dev. 2015, 78, 461-476. [CrossRef]

99. National Bureau of Statistics. China City Statistical Yearbook 2016; China Statistics Press: Beijing, China, 2017.

100. National Health and Family Planning Commission in China. Migrant Dynamics Monitoring Survey (MDMS) in 2016; The National Health and Family Planning Commission in China: Beijing, China, 2017.

101. China Index Academy. China Real Estate Statistics Yearbook 2016; China Statistics Press: Beijing, China, 2017.

102. National Health and Family Planning Commission in China. Migrant Dynamics Monitoring Survey (MDMS) in 2011; The National Health and Family Planning Commission in China: Beijing, China, 2012.

103. Dong, X.; Zhou, W.H. Housing affordability and permanent migration intension of rural-urban migrants. Chin. J. Urban Environ. Stud. 2016, 4, 1650019. [CrossRef]

104. Yang, Z.; Zhang, X.L.; Lei, J.; Duan, Z.L.; Li, J.G. Spatio-temporal pattern characteristics of relationship between urbanization and economic development at county level in China. J. Geogr. Sci. 2019, 29, 553-567. [CrossRef]

105. Liu, Q.; Wang, S.J.; Zhang, W.Z.; Li, J.M.; Kong, Y.L. Examining the effects of income inequality on $\mathrm{CO}_{2}$ emissions: Evidence from non-spatial and spatial perspectives. Appl. Energy 2019, 236, 163-171. [CrossRef]

106. Mehic, A. Industrial employment and income inequality: Evidence from panel data. Struct. Chang. Econ. Dyn. 2018, 45, 84-93. [CrossRef]

107. Sun, J.; Zhao, M. The changing structure of China's Pearl River Delta megacity region. J. Reg. City Plan. 2018, 29, 169-187.

108. Liao, L.P.; Wang, C.C. Urban amenity and settlement intentions of rural-urban migrants in China. PLoS ONE 2019, 14, e0215868. [CrossRef]

109. Liu, J.; Zhang, Q.; Hu, Y. Regional differences of China's urban expansion from late 20th to early 21st century based on remote sensing information. Chin. Geogr. Sci. 2012, 22, 1-14. [CrossRef] 
110. Li, Y.Z. Urbanization and economic growth in China: An empirical research based on VAR model. Int. J. Econom. Fin. 2017, 9, 210-219.

111. Liu, L. The main problems and policy suggestions of urban housing security system in China. China Econ. Trade Her. 2008, 24, 30-33. (In Chinese)

112. Qin, X.H.; Du, D.B. Do external or internal technology spillovers have a stronger influence on innovation efficiency in China? Sustainability 2017, 54, 1574.

113. Han, W.; Zhang, Y.; Cai, J.M.; Ma, E. Does urban industrial agglomeration lead to the improvement of land use efficiency in China? An empirical study from a spatial perspective. Sustainability 2019, 11, 986. [CrossRef]

114. Cui, C.; Hooimeijer, P.; Geertman, S.; Pu, Y.X. Residential distribution of the emergent class of skilled migrants in Nanjing. Hous. Stud. 2015, 30, 1235-1256. [CrossRef]

115. Liu, Z.; Jiang, W.; Peng, Y.; Wu, Y. Advantages of agent construction in building university talent apartments in China. In Proceedings of the 20th International Symposium on Advancement of Construction Management and Real Estate, Hangzhou, China, 23-25 October 2017.

116. Wu, Y.M.; Zhu, S.; Fan, J.Q. Spatial-temporal statistical analysis of Chengdu-Chongqing regional economic structure evolution based on comparative study with five major economic regions and four major urban groups. In Proceedings of the International Conference on Management Science \& Engineering, Rome, Italy, 13-15 September 2011; Volume 18, pp. 702-708.

117. Costello, L. Urban-rural migration: Housing availability and affordability. Aust. Geogr. 2009, 40, $219-233$. [CrossRef]

118. Chu, Z.P.; Liu, C.X.; Li, G.; Guan, K.X. Sustainable development of the economic circle around Beijing: A view of regional economic disparity. Sustainability 2018, 10, 3691. [CrossRef]

119. Tian, Y.Y.; Jiang, G.H.; Zhou, D.Y.; Ding, K.S.; Su, S.; Zhou, T.; Chen, D.B. Regional industrial transfer in the Jingjinji urban agglomeration, China: An analysis based on a new "transferring area-undertaking area-dynamic process" model. J. Clean. Prod. 2019, 235, 751-766. [CrossRef]

120. Zhang, W.X.; Nian, P.H.; Lyu, G.W. A multimodal approach to assessing accessibility of a high-speed railway station. J. Transp. Geogr. 2016, 54, 91-101. [CrossRef]

121. Huang, Y.C.; Nian, P.H.; Zhang, W.X. The prediction of interregional land use differences in Beijing: A Markov model. Environ. Earth Sci. 2014, 73, 4077-4090. [CrossRef]

122. Cao, X.Z.; Zeng, G.; Ye, L. The structure and proximity mechanism of formal innovation networks: Evidence from Shanghai high-tech ITISAs. Growth Chang. 2019, 50, 569-586. [CrossRef]

123. Sun, Y.F.; Du, D.B. Domestic firm innovation and networking with foreign in China's ICT industry. Environ. Plan. A 2011, 43, 786-809. [CrossRef]

124. Xu, D.; Hou, G.L. The spatiotemporal coupling characteristics of regional urbanization and its influencing factors: Taking the Yangtze River Delta as an example. Sustainability 2019, 11, 822. [CrossRef]

125. Hui, E.C.M.; Gu, Q. Study of Guangzhou house price bubble based on state-space model. Int. J. Strateg. Prop. Manag. 2009, 13, 287-298. [CrossRef]

126. LeSage, J.P. Bayesian estimation of spatial autoregression models. Int. Reg. Sci. Rev. 1997, 20, $113-129$. [CrossRef]

127. LeSage, J.P.; Pace, R.K. Introduction to Spatial Econometrics; Chapman and Hall: New York, NY, USA, 2009.

128. Anselin, L. Thirty years of spatial econometrics. Pap. Reg. Sci. 2010, 89, 3-25. [CrossRef]

129. Elhorst, J.P.; Zeilstra, A.S. Labour force participation rates at the regional and national levels of the European Union: An integrated analysis. Pap. Reg. Sci. 2007, 86, 525-549. [CrossRef]

130. Chen, S.; Li, G.; Xu, Z.; Zhuo, Y.; Wu, C.F.; Ye, Y. Combined impact of socioeconomic forces and policy implications: Spatial-temporal dynamics of the ecosystem services value in Yangtze River Delta, China. Sustainability 2019, 11, 2622. [CrossRef]

131. Zhang, W.W.; Sharp, B.; Xu, S.C. Does economic growth and energy consumption drive environmental degradation in China's 31 provinces? New evidence from a spatial econometric perspective. Appl. Econ. 2019, 51, 4658-4671. [CrossRef]

(C) 2019 by the authors. Licensee MDPI, Basel, Switzerland. This article is an open access article distributed under the terms and conditions of the Creative Commons Attribution (CC BY) license (http://creativecommons.org/licenses/by/4.0/). 